\title{
Vitamin D in Neurological Diseases: A Rationale for a Pathogenic Impact
}

\author{
Rita Moretti * (1), Maria Elisa Morelli ${ }^{(1)}$ and Paola Caruso \\ Neurology Clinic, Department of Medical, Surgical and Health Sciences, University of Trieste, Strada di Fiume, \\ 447, 34149 Trieste, Italy; mariaelisa.morelli@gmail.com (M.E.M.); caruso.paola1983@libero.it (P.C.) \\ * Correspondence: moretti@units.it
}

Received: 27 June 2018; Accepted: 26 July 2018; Published: 31 July 2018

check for updates

\begin{abstract}
It is widely known that vitamin D receptors have been found in neurons and glial cells, and their highest expression is in the hippocampus, hypothalamus, thalamus and subcortical grey nuclei, and substantia nigra. Vitamin D helps the regulation of neurotrophin, neural differentiation, and maturation, through the control operation of growing factors synthesis (i.e., neural growth factor [NGF] and glial cell line-derived growth factor (GDNF), the trafficking of the septohippocampal pathway, and the control of the synthesis process of different neuromodulators (such as acetylcholine [Ach], dopamine [DA], and gamma-aminobutyric [GABA]). Based on these assumptions, we have written this review to summarize the potential role of vitamin $\mathrm{D}$ in neurological pathologies. This work could be titanic and the results might have been very fuzzy and even incoherent had we not conjectured to taper our first intentions and devoted our interests towards three mainstreams, demyelinating pathologies, vascular syndromes, and neurodegeneration. As a result of the lack of useful therapeutic options, apart from the disease-modifying strategies, the role of different risk factors should be investigated in neurology, as their correction may lead to the improvement of the cerebral conditions. We have explored the relationships between the gene-environmental influence and long-term vitamin D deficiency, as a risk factor for the development of different types of neurological disorders, along with the role and the rationale of therapeutic trials with vitamin D implementation.
\end{abstract}

Keywords: neuro-degeneration; MS; demyelination; vascular disease; stroke; AD; vitamin D-OH 25; VDR; VDH; calcium

\section{Introduction}

Low levels of vitamin D, considering serum 25-hydroxyvitamin D $(25(\mathrm{OH}) \mathrm{D})$, have been recognized as a widespread health problem, affecting approximately one billion people worldwide [1]. Latitude, season, cultural norms, religious practices, limited awareness, lack of knowledge, indoor lifestyles, urban living, skin pigmentation, malnutrition, diet, co-morbidities (like tuberculosis, malnutrition, chronic inflammatory conditions, etc.), and drugs, may contribute to vitamin D deficiency, especially in the developing world, even if some genetic predispositions can interfere with it (i.e., blacks tend to have lower levels of $25(\mathrm{OH}) \mathrm{D}$ compared to whites) [2,3].

Vitamin D is a lipid-soluble vitamin, which can be synthesized and act as a hormone [4]. The active form of vitamin $\mathrm{D}, 1,25(\mathrm{OH})_{2} \mathrm{D}$, known as calcitriol, has chemical similarities to typical hormones, such as testosterone, estrogen, and cortisol.

Vitamin D yields both genomic and non-genomic actions; the Vitamin D Receptors (VDR) mediates the former, one of the representative of the steroid hormone superfamily, which are evident in more than 30 human tissues, therefore regulating 3\% of the human genome (approximately 700 genes) [5]. Nuclear VDRs are found in most cells, and support the role for the extra-skeletal benefits of vitamin D. The VDR are found in almost all human tissues, participating in the classic actions of vitamin $\mathrm{D}$ in the 
bone, gut, and kidney, but are also involved in immune functions, hormone secretion, and cellular proliferation and differentiation [6]. To be biologically active, vitamin D undergoes hydroxylations in the liver, mediated by the 25-hydroxylase, and in the kidney, mediated by $1 \alpha$-hydroxylase. The $1,25(\mathrm{OH})_{2} \mathrm{D}$ is recognized by VDR, in various cells, mainly in the intestine. As vitamin D plays a significant role in modulating the immune system in the intestine, it is possible that its deficiency could deteriorate the gut barrier function, favoring the translocation of endotoxins. Vitamin D deficiency has been associated with intestinal dysbiosis and increased susceptibility to intestinal diseases; moreover, vitamin $\mathrm{D}$ could be contributing to disturbances of the glucose metabolism by modulating the composition of the gut microbiota. The changed intestinal microbiome has become epidemic, in parallel with the epidemic of vitamin D deficiency, suggesting that they might be linked. Proper supplemental doses of vitamin D plus all of the B vitamins appears to return the intestinal microbiome back to normal after few months [7,8]. Moreover, there are more and more evidence that links the microbiome to neurologic disorders [9], which can share a common auto-immune involvement; the potential link between the three actors (VDR, neurological disorders, and vitamin D) is quite fascinating and many studies should be done to gain knowledge on them.

The non-genomic actions of vitamin D help to cooperate with the classical genomic pathway, to transactivate VDR, and exert the effects of calcitriol; the signal does not depend on the transcription phases, but it can operate via cross-talk with different signaling pathways, such as rapid membrane response binding proteins (see later). The genomic and the non-genomic pathways support the emerging not calcemic effects of the vitamin D metabolites, trying to define a role in the autoimmune pathologies, infectious diseases, diabetes mellitus, obesity, and cardio-metabolic disorders [10].

It has also been demonstrated that Vitamin D is involved in different neurological disorders, such as multiple sclerosis, Alzheimer's disease, Parkinson's disease, and stroke [11-14].

The presence of VDR in the hippocampus, hypothalamus, thalamus, cortex, and substantia nigra [15] prompted many studies on the possible determinant role of vitamin $\mathrm{D}$ in different neurological conditions [16,17]. It has been evidenced that calcitriol is a fundamental actor in the neuronal differentiation and the neural maturation [18]. Vitamin D normalizes the trafficking of the septo-hippocampal pathways, mainly via the neural growth factor (NGF); moreover, it is an active controller of the genetic regulation of the synthesis of acetylcholine (Ach), dopamine (DA), serotonin (5HT3), and gamma-aminobutyric (GABA) [19-21].

The knock-out model of $\mathrm{VDR}^{-/-}$has an accelerated aging process in all of the organs, as well as in the brain [22,23], with a significant in-brain decrease of NGF [24] and other neurotransmitters, such as Ach $[25,26]$. The congenital deficiency of vitamin D significantly reduces the activity of glutamic acid decarboxylase (GAD) 65/67 (critical enzymes in GABAergic inter-neurons) and the levels of glutamate and glutamine in the brain tissue [27].

For these reasons, we reckon that a vitamin D deficiency could contribute to the complex relationship between genetics and the environment, the two common poles that many neurological pathologies debate between. It could intervene in the exacerbation of precipitating factors or in demodulating the repair process; therefore, we consider that this topic should be approached from a neurological perspective. Therefore, we have started this review. We searched MEDLINE using the following search terms: "vitamin D central nervous system", both "vitamin D" and "central nervous system"; "vitamin D immune system/response", both "vitamin D" and "immune system" or "immune response"; "vitamin D multiple sclerosis risk", both "vitamin D" and "multiple sclerosis risk"; "vitamin D multiple sclerosis relapse", both "vitamin D" and "multiple sclerosis relapse"; "vitamin D multiple sclerosis magnetic resonance imaging", both "vitamin D" and "multiple sclerosis magnetic resonance imaging"; "vitamin D multiple sclerosis disability", both "vitamin D" and "multiple sclerosis disability"; "vitamin D supplementation/therapy/treatment multiple sclerosis", both "vitamin D supplementation" or "vitamin D therapy" or "vitamin D treatment" and "multiple sclerosis"; "vascular dementia", both "vascular" and "dementia"; "subcortical vascular dementia", both "subcortical" and "dementia"; "Alzheimer's disease"; "pathogenesis neural-degeneration"; "amyloid"; "cholinergic afferents"; "arteriolosclerosis"; "cerebral 
flow regulation"; and "stroke". The publications that were selected were mostly from the past 20 years, but they did not exclude the frequently referenced and highly regarded older publications. The research has been extended, with the same strings, EMBASE, COCHRANE LIBRARY, and LILACS. All of the searches were done from 1 January 1993 up to 31 May 2018. We considered papers published in English, French, German, and Italian. Congress abstracts and isolated case reports (even if the total cases were under 10) were not considered. Review articles and book chapters are cited to provide additional details. The authors carefully read all of the selected articles.

\section{Vitamin D Deficiency and Multiple Sclerosis: Role in the Susceptibility, Activity, and Treatment of the Disease}

Multiple Sclerosis (MS) is a multifactorial demyelinating pathology affecting the brain and the spinal cord, firmly relying on an altered immune response. Activated autoreactive $\mathrm{T}$ cells invade the blood-brain barrier and initiate an inflammatory response that leads to myelin destruction and axonal loss. The etiology of MS, the mechanisms associated with its onset, the unpredictable clinical course, and the different rates of progression leading to disability over time, remain unresolved questions [28].

Immunological research makes two significant observations to explain the link between vitamin $D$ and the immune system.

Firstly, most immune cells, of both the innate and the adaptive immune system, express the VDR $[29,30]$. Secondly, the immune cells exhibit an active vitamin D metabolism, with the expression of the rate-limiting enzyme for vitamin D synthesis, $1 \alpha$-hydroxylase (CYP27B1) [31]. Immune cells are, therefore, able to synthesize and secrete vitamin $\mathrm{D}$ in an autocrine and paracrine condition [32]. The immune cell types, targeted by vitamin $\mathrm{D}$, include monocytes and macrophages, dendritic cells (DCs), and $\mathrm{T}$ and $\mathrm{B}$ cells [33]. 1,25(OH) 2 vitamin $\mathrm{D}$ induces monocytes proliferation and differentiation into macrophages [34], the potentiate the expression of interleukin-1 (IL-1), and the antimicrobial peptides (cathelicidin, $\beta$-defensin-2, and hepcidin) [35]. Vitamin D inhibits DC differentiation and maturation, their major histocompatibility complex (class II) expression (MHC), CD40, CD80, CD86, and IL-12 (while inducing the production of IL-10), leading to reduced T cell stimulatory capacity $[36,37]$. Vitamin D decreases the production of nitric oxide (NO), mediating the downregulation of the inducible nitric oxide synthase (iNOS) expression [38]. Moreover, it stimulates the development of natural killer T (NKT) cells, and it increases IL-4 and interferon (IFN)- $\gamma$ production [39]; vitamin $\mathrm{D}$ attenuates the proliferation of CD8+ T cells and reduces their cytotoxic activity by decreasing the production of IL-2, IL-17, and IFN- $\gamma$.

Vitamin D exerts its immunomodulatory effects on T lymphocytes, by inhibiting the production of pro-inflammatory Th1 cytokines (IL-1, IL-2, IL-6, IL-12, IFN- $\gamma$, TNF- $\alpha$, and TNF- $\beta$ ), and stimulating the production of anti-inflammatory regulatory Th2 cytokines (IL-4, IL-5, and IL-10) [40,41].

Thus, vitamin D potentiates the innate immune system and regulates the adaptive immune system, mainly by inducing the split to Th2 and regulatory T cells (Tregs), over the Th1 and Th17 lymphocytes differentiation [42], via direct and indirect actions on naive CD4+ cells. The general result is an evident effect of switching capacity, from a pro-inflammatory autoimmune to an anti-inflammatory tolerogenic immunological response.

In multiple sclerosis (MS) patients, the blood level of $25(\mathrm{OH}) \mathrm{D}$ or $1,25(\mathrm{OH})_{2} \mathrm{D}$ has been linked with the suppressive activity of Tregs [43], and the number of Tregs has been correlated with the serum levels of $25(\mathrm{OH}) \mathrm{D}$ or $1,25(\mathrm{OH})_{2} \mathrm{D}$. The Tregs are increased in the MS patients that have supplemented with vitamin D [44,45].

According to many studies, vitamin D may have an impact on the balance between the inflammatory and anti-inflammatory mechanisms, which might help/regulate the remyelination process. Vitamin D increases the microglial activation, promoting the clearance of myelin debris, and consequently activating the remyelination process [46]. In the oligodendrocyte precursor cells (OPC) cultures, vitamin D up-regulates the transcription of VDR and NGF mRNA, but not of myelin basic protein (MBP) [47-49]. The remyelination of demyelinated lesions has been observed in the early stages 
of MS [50,51], and it has been supported by neuroimaging findings [52,53]. However, remyelination might be incomplete [54], and eventually, it might cease [55], because of the OPC inability to migrate and reach the site of demyelination [56], or for the OPC differentiation inability [57]. In fact, an inflammatory microenvironment prevents OPC maturation and the differentiation into oligodendrocytes, and subsequently prevents axon remyelination. This is relevant for MS treatment, as current treatments are only useful for controlling immune mechanisms (i.e., in the early stages of the disease), but do not affect remyelination. In vitro studies show that when blocking VDR, there is a reduction of OPC differentiation, with a consequent blockage of myelination and remyelination; on the other hand, by activating VDR, via vitamin D, there is an increase in the differentiation of OPC and the consequent remyelination [58]. Likewise, neural stem cells (NSC) express VDR and $1,25(\mathrm{OH})_{2} \mathrm{D}$, which seems to promote the NCS proliferation and differentiation into neurons and oligodendrocytes, and to reduce astrogliosis $[59,60]$.

As vitamin D deficiency has been proposed as a significant risk factor in MS development, most epidemiologic observational studies have suggested that adequate vitamin D levels may reduce the risk of MS onset and modify the course of the disease. MS is a disease that is virtually unknown at the equator, and the prevalence of the disease increases in populations that live farther away from the equator [61]. The prevalence of MS is higher at higher latitudes, and tends to peak in the areas with the lowest exposure to ultraviolet (UV) light [62,63]; however, in these areas, diets rich in vitamin D-containing oily fish may offset this risk to some degree [62-65]. Moreover, the risk of MS has been found to decrease among people who migrate from higher to lower latitudes [66]. This latitudinal finding has been declining in recent decades, instead of an associated increasing trend towards avoiding sun exposure by staying indoors for more extended periods of the day, even in warmer climates $[67,68]$. In fact, higher levels of sun exposure (past, recent, and cumulative) were independently associated with higher levels of vitamin D and with a significantly reduced risk of developing demyelinating events [69]. Sunlight seems to have an immunosuppressive effect and, therefore, the effects of sunlight on MS risk could be related to the sunlight itself, or to an increase of vitamin D [70]. The association between the calculated vitamin D intake from diet or supplements, and the risk of developing MS has been prospectively evaluated in two large cohorts involving more than 187,000 women [71]. Women who had a higher intake of dietary vitamin D (approximately $700 \mathrm{IU} /$ day) had a 33\% lower incidence of MS compared with those with a lower intake. Moreover, the women who used vitamin D supplements (more than $400 \mathrm{UI} /$ day) had a $41 \%$ reduced risk of developing MS compared with non-users. Higher levels of 25(OH)D (independently, from dietary vitamin D intake) also seem to predict a lower risk of MS onset. A more recent prospective study confirmed these findings and reported that the levels of vitamin D over $30 \mathrm{ng} / \mathrm{mL}$ were associated with a decreased MS risk [72]. Adiposity has been associated with lower vitamin D levels [73,74], and a higher body mass index (BMI) has been associated with higher incidence of MS in adolescent women, but not in adult women [75].

A crucial question related to a primary prevention trial or from vitamin D supplementation in MS is the relevant age of exposure, which can range from in utero to adolescence and adulthood [76]. Mirzaei et al. studied a large cohort and analyzed the association between maternal dietary vitamin D intake and the predicted maternal serum $25(\mathrm{OH}) \mathrm{D}$ during pregnancy, and their daughters' risk of developing MS [77]. The study showed that the relative risk of MS was significantly lower in the women whose mothers had high vitamin D intake during pregnancy compared with the women born to low-intake mothers. A diminished in utero exposure to vitamin D, coupled with the solar cycle and latitudinal differences, may be an environmental risk factor for the development of MS. Similarly, albeit not statistically significant, a reduced MS risk was reported among the women reporting an increased vitamin D intake from supplements in adolescence [78]. These results suggest that MS risk is related not only to new vitamin D levels, but it might also be related to its levels during childhood or even in utero. Several studies, including a meta-analysis, demonstrated that spring-born have a significantly higher lifetime MS risk than autumn-born, which has been attributed, at least in part, to insufficient 
in utero vitamin D levels, because of low maternal serum vitamin D levels during winter $[79,80]$. In a large population-based case-control study [81], children born with 25(OH)D levels $<10 \mathrm{ng} / \mathrm{mL}$ seemed to be at a high risk of developing MS. Likewise, the level of sun exposure in childhood and adolescence (e.g., by outdoor leisure activities), which may serve as a proxy for vitamin D supply in early life, has been inversely linked to the risk of MS in adulthood [82,83]. In a recent longitudinal Canadian study of 302 children with the acute demyelinating syndrome, low vitamin D levels were significantly associated with MS risk in the subsequent three years [84]. One report showed that children with higher serum $25(\mathrm{OH}) \mathrm{D}$ concentrations at presentation, with an acquired demyelinating syndrome, had a lower risk of early MS diagnosis [85]. Gender- and sex-related immunological differences may influence the association between vitamin D and MS. The disproportional increase in the incidence of MS in women is likely to be caused by sex-specific exposure or susceptibility to environmental factors [86]. The data supporting an interaction between female sex, possibly mediated by estrogen, and vitamin D for MS risk is accumulating. A protective effect of sun exposure was only observed in female monozygotic twins [87], and the association of sun-sensitive skin types with a disability was only found in untreated female MS patients [88]. In vitro studies of MBP-specific T cell proliferation have shown sex differences in the metabolism of vitamin $\mathrm{D}$, which were confirmed by treating male MBP-specific T cells with $17 \beta$-estradiol in the assay [89]. In one animal study, vitamin $D$ resulted in fewer clinical, histopathologic, and immunologic signs of Experimental Autoimmune Encephalomyelitis (EAE) in female mice compared with ovariectomized females and intact or castrated males [90]. A synergy between $\mathrm{E}_{2}$ and vitamin D occurred through the VDR-mediated enhancement of $E_{2}$ synthesis, as well as through the $E_{2}$-mediated enhancement of VDR expression due to the inflammation of central nervous system (CNS). In males, $E_{2}$ did not enable vitamin D to inhibit EAE [91], possibly suggesting that vitamin D-mediated protection in EAE is female-specific, and that MS tends to have a more aggressive course in men than in women.

Several genome-wide association studies (GWAS) and gene-candidate studies have investigated the influence of the specific genetic polymorphisms of vitamin D metabolites on the 25(OH)D levels, and their susceptibility to MS; one study found [92] an association between the short variant of the VDR protein (F allele) and a genetic predisposition to lower 25(OH)D levels, but not to a higher risk of MS; in a GWAS of 4501 European patients [93], single-nucleotide polymorphisms (SNPs) of the gene encoding components of the vitamin D binding protein were associated with $25(\mathrm{OH}) \mathrm{D}$ concentrations, or with the genes involved in vitamin $\mathrm{D}$ synthesis or activation; moreover, a genetically lowered $25(\mathrm{OH}) \mathrm{D}$ level was strongly associated with increased MS risk and progression in two studies [94,95].

The role of vitamin D in MS disease progression has also been assessed: it has been hypothesized that $25(\mathrm{OH}) \mathrm{D}$ levels can predict a later development of MS in acute optic neuritis $(\mathrm{ON})$ [96], but the result is inconclusive. A discrete quantity of studies demonstrated that vitamin D levels affect clinical relapses and MS disease activity. In a retrospective study of 110 patients with pediatric-onset MS, the authors found that each increase of $10 \mathrm{ng} / \mathrm{mL}$ in the $25(\mathrm{OH}) \mathrm{D}$ level was associated with a $34 \%$ decrease in the relapse risk [97]. Similar findings were seen in a prospective cohort study, whose authors concluded that raising $25(\mathrm{OH}) \mathrm{D}$ by $20 \mathrm{ng} / \mathrm{mL}$ could decrease the hazard of relapse by up to $50 \%$ [98]. In a prospective longitudinal study, the relapse risk was significantly reduced in those patients with medium (20-40 $\mathrm{ng} / \mathrm{mL}$ ) and high $(>40 \mathrm{ng} / \mathrm{mL})$ serum vitamin D levels, compared with those with low levels $(<20 \mathrm{ng} / \mathrm{mL})$ [99]. Moreover, the same authors found that for each doubling of the serum vitamin D concentration from a baseline of 10, 20, and $30 \mathrm{ng} / \mathrm{mL}$, MS relapse risk decreased by $27 \%$. In another study, lower vitamin D levels predicted a conversion from Clinically Isolated Syndrome (CIS) to clinically definite MS $[100,101]$. In the study by Embry et al., low serum $25(\mathrm{OH}) \mathrm{D}$ levels predicted an increased likelihood of gadolinium-enhancing lesions ( $\mathrm{Gd}+$ ) in the Magnetic Resonance Imaging (MRI) scans performed in the subsequent two months period [102]. In the EPIC study [103], a five-year MS cohort study in which subjects had clinical and MRI evaluations and gave a blood sample annually. The authors concluded that individuals with CIS/relapsing-remitting multiple sclerosis (RRMS) with higher vitamin D levels have a lower risk of the subsequent development of new T2 lesions and 
Gd+ lesions on a brain MRI, even after accounting for potential confounding factors. Moreover, an increment of $10 \mathrm{ng} / \mathrm{mL}$ of $25(\mathrm{OH}) \mathrm{D}$ was associated with a $15 \%$ lower risk of new T2 lesions and a $32 \%$ lower risk of $\mathrm{Gd}+$ lesions [103]. In a post hoc analysis, including up to two years of follow-up of participants treated with interferon beta (IFNB)-1b in the BENEFIT trial [104], Gd+ lesions development was inversely associated with $25(\mathrm{OH}) \mathrm{D}$ levels, those patients whose $25(\mathrm{OH}) \mathrm{D}$ levels were $>20 \mathrm{ng} / \mathrm{mL}$ had a $39 \%$ lower risk of new Gd+ lesions. Unfortunately, across all of the analyses, associations with lower vitamin D were generally stronger for MRI than for the clinical outcomes. Moreover, the participants of the Betaferon Efficacy Yielding Outcomes of a New Dose (BEYOND) study (BEYOND study) [105], treated with IFNB-1b, with higher serum 25(OH)D levels, had lower numbers of new T2 and $\mathrm{Gd}+$ lesions during the first 12 months of follow-up. Moreover, a $20 \mathrm{ng} / \mathrm{mL}$ higher serum $25(\mathrm{OH}) \mathrm{D}$ level was associated with a $31 \%$ lower rate of new lesions, and the patients with $25(\mathrm{OH}) \mathrm{D} \geq 40 \mathrm{ng} / \mathrm{mL}$ showed $47 \%$ lower rate of new T2 lesions and new $\mathrm{Gd}+$ lesions, when compared with the patients who had serum levels of 20-32 ng/mL. Vitamin D and disease-modifying therapies (DMTs) may positively influence each other and produce an additive, or even synergistic, effect on MS disease activity. In an observational cohort study, which included 178 patients with MS [106], the patients who were treated by IFN had significantly higher $25(\mathrm{OH}) \mathrm{D}$ levels than those who were not. Interestingly, the IFN treatment was protective only against relapses among the patients with higher vitamin D levels. The authors hypothesized that treatment with IFNB might increase the serum vitamin D levels through an enhanced responsiveness to sun exposure [106]. The same authors did not find similar associations for glatiramer acetate (GA) therapy and vitamin D. More recently, Laursen et al. [107] found that higher vitamin D levels in CIS may slow neurodegeneration evaluated by brain volume measures. In fact, they found that each $10 \mathrm{ng} / \mathrm{mL}$ increase in $25(\mathrm{OH}) \mathrm{D}$ was significantly associated with a $7.8 \mathrm{~mL}$ higher gray matter volume [108]. Variations in the relapse rate and the number of MRI brain lesions have shown a seasonal pattern that can be related to a variation in Ultra Violet Radiation (UVR) exposure and vitamin D status [109,110], with some exceptions [111,112]. Most cross-sectional studies have concluded a negative correlation between the $25(\mathrm{OH}) \mathrm{D}$ level and disability $[103,113,114]$, and, interestingly, even a direct correlation between the $25(\mathrm{OH}) \mathrm{D}$ level and poorer memory performance [115]. However, the causality is considered uncertain, at the moment.

Given the previous reviewed findings, the assessment of vitamin D supplementation for a possible disease-modifying course of MS is obviously of crucial interest. Unfortunately, the current evidence does not offer a definite consensus for supplementation. Kimball et al. [115] performed a six-month safety study with escalating doses of vitamin D, and they found a significant reduction in the mean number of $\mathrm{Gd}+$ lesions at the end of the study. In an open-label randomized trial, patients randomized to a vitamin D supplementation had an annualized relapse rate (ARR) significantly lower in the treatment, with a prolonged relapse-free time and with a persistent reduction in the $\mathrm{T}$ cell proliferation [44]. In a one year double-blind, randomized placebo-controlled trial with vitamin D3 as an add-on treatment to IFNB-1b, the MRI T2 lesion burden and the new/enlarging $\mathrm{T} 2$ lesions, tended to increase more in the placebo group than in the vitamin $\mathrm{D}$ group, however, without statistical significance [116]. A preliminary Iranian study assessed the safety and efficacy of high-dose vitamin D supplementation during pregnancy in women with MS [117]. The women in the vitamin D group had significantly fewer relapses during pregnancy, a tendency for fewer relapses up six months after delivery, and a more stable Expanded Disability Status Scale (EDSS) than those without supplementation [107]. In a longitudinal study [118], in which 170 natalizumab-treated patients were followed for one year between two winter seasons, patients with insufficient serum $25(\mathrm{OH})$ D levels at baseline $(<20 \mathrm{ng} / \mathrm{mL})$ were advised to take vitamin D supplements, and a significant inverse relationship with the ARR was found, as, for each nmol/L increase in $25(\mathrm{OH}) \mathrm{D}$, a 0.014 decrease in ARR was observed. The double-blind, multicentre, 48-week study, named SOLAR, of supplementation of high-dose oral vitamin D has been the most extensive study to date [119]. An insignificant trend toward lower ARR in the treatment group was found in vitamin $\mathrm{D}$ groupersus placebo, and no statistically significant differences in the disease activity were found between the two 
groups. Vitamin D3 was associated with a statistically significant reduction in the combined unique lesions (secondary endpoint). The effect of the addition of vitamin D3 to IFNB-1a over 96 weeks was investigated with appropriate cognitive tests [120]. It did not show a significant trend toward a lower ARR (primary endpoint) among those patients receiving vitamin D treatment, which became statistically significant when the analysis was restricted to those who completed the study. Among the completers, there were also significantly fewer new T2 lesions in the vitamin D group. It is unclear whether the findings of these trials are related to insufficient power or other issues leading to an inability to detect a treatment effect for all outcomes [120].

Larger randomized controlled trails (RCTs) are currently underway to reveal the role of vitamin D supplementation as an add-on to IFNB therapy in the treatment of RRMS, and even CIS, patients, namely, the VITADEM study in Spain, EVIDIMS study in Germany, PrevANZ study in Australia, D-Lay-MS study in France, and the VIDAMS trial in the United States. One study investigated the cognitive effects of vitamin D supplementation on patients with MS who were treated with IFNB [121], and after the follow-up period they scored better on the Brief Visuospatial Memory test (BVMT) for delayed recall.

In conclusion, numerous studies suggest that vitamin D supplementation may benefit MS patients, although larger RCTs are needed to establish this supplementation as a standard of care for MS. Moreover, there is no consensus on the definition of 'sufficient' vitamin D levels in MS, and many physicians question whether people with MS should empirically be supplemented while waiting for more conclusive results of vitamin D clinical trials. In the view of the Institute of Medicine (IOM), 25(OH) D levels greater than $20 \mathrm{ng} / \mathrm{mL}(50 \mathrm{nmol} / \mathrm{L})$ are sufficient. The Endocrine Society, considering skeletal and non-skeletal health, argues for levels of almost $30 \mathrm{ng} / \mathrm{mL}(75 \mathrm{nmol} / \mathrm{L})$. In the MS field, numerous studies suggest that serum $25(\mathrm{OH}) \mathrm{D}$ levels of approximately $40 \mathrm{ng} / \mathrm{mL}(100 \mathrm{nmol} / \mathrm{L})$ are the lower limit for controlling MRI and clinical activity. Some experts favor maintaining $25(\mathrm{OH}) \mathrm{D}$ levels between 30 and $50 \mathrm{ng} / \mathrm{mL}$ in MS patients, as immune-modulatory effects have been observed in these ranges in experimental studies. Longitudinal RCTs are needed to establish the recommended levels of vitamin D supplementation necessary to reduce the risk of MS onset and MS pathological activity. According to other authors [122], for individuals with CIS or MS and vitamin D deficiency ( $<20 \mathrm{ng} / \mathrm{mL}$ ), an 'attack' supplementation with 50,000 IU/week of vitamin D2 (ergocalciferol) for eight weeks, and a subsequent evaluation of the serum level, is recommended. The continuation of this therapy until the serum $25(\mathrm{OH}) \mathrm{D}$ is higher than $30 \mathrm{ng} / \mathrm{dL}$ may be necessary. A maintenance supplementation with vitamin D3 (cholecalciferol) at 1000 to $2000 \mathrm{IU} /$ day may be started when the deficiency has been corrected, and at once in case of vitamin D insufficiency $(20-29 \mathrm{ng} / \mathrm{mL}$ ). As current evidence also suggests both an obstetric and pediatric benefit from vitamin D against the risk of developing MS, vitamin D supplementation in children and pregnant women at risk of developing or being affected by MS should be considered [123]. According to other authors, as a goal, the general aim is $25(\mathrm{OH}) \mathrm{D}$ levels between 40 and $60 \mathrm{ng} / \mathrm{mL}$, and most patients should take a dose that arises from 2000 to $5000 \mathrm{IU} /$ day vitamin D3 [123]. Many studies have been conducted to show the potential relationships between genome-wide association studies (GWAS) and gene-candidate studies, in order to find out the specific genetic polymorphisms of the vitamin D metabolites on the 25(OH)D levels, and their susceptibility to MS and to vitamin D supplementation efficacy in MS [92-95]. Moreover, the Human Leukocyte Antigen (HLA) haplotype might influence epistasis, trans and cis effects, and parent-of-origin effects, as well as the Epstein Barr Virus (EBV) and vitamin D effects on the course of MS [124]. Le Mokry et al. (2015) identified SNPs associated with 25(OH)D level from SUNLIGHT, the largest $(n=33,996)$ genome-wide association study to date for vitamin D. Four SNPs were genome-wide significant for 25(OH)D levels, and all four SNPs lay in, or near, genes strongly implicated in separate mechanisms influencing $25(\mathrm{OH}) \mathrm{D}$. The authors found out that the count of the $25(\mathrm{OH}) \mathrm{D}$-decreasing alleles across these four SNPs was strongly associated with a lower $25(\mathrm{OH}) \mathrm{D}$ level. Other recent perspectives [95] confirmed the research by Ahn et al. [93]; it seems that there are strong links between the 25(OH)D levels and the genotyping of CYP2R1- and NAD-synthetase 
(NADSYN1-SNPs) in MS patients. The analysis revealed lower 25(OH)D concentrations in MS patients and an association of rs10766197 CYP2R1 SNP with MS risk. After stratifying the MS patients according to gender, the authors [95] found that the minor allele A of rs10766197 had a higher frequency in men in comparison with the women affected by MS. Additionally, the presence of allele A in men was associated with disease progression, assessed by EDSS and Multiple Sclerosis Severity Score (MSSS) scores [96]. The results are not univocal at all; a recent study focussed on VDR polymorphisms (Fok-I, Bsm-I, Taq-I, and Apa-I) that were genotyped by a polymerase chain reaction (PCR), followed by the restriction fragment length polymorphism (RFLP) analyses in both groups, and the serum $25(\mathrm{OH})$ D levels were determined in the MS patients by high-performance liquid chromatography (HPLC). The distribution of genotype and allele frequencies of the four VDR polymorphisms did not differ significantly between the MS patients and healthy controls, and were unrelated to the forms and the course of MS. Low serum levels of $25(\mathrm{OH}) \mathrm{D}$ were observed in MS patients, but no association was observed between the VDR and 25(OH) D levels, except for Fok-I. Moreover, the MS patients with the $F F$ and $F f$ genotype had a significantly lower serum level of $25(\mathrm{OH}) \mathrm{D}$ [92]. Moreover, further studies are necessary to develop potential relationships between the genome-wide association studies (GWAS) and gene-candidate studies for determining the influence of specific genetic polymorphisms of the vitamin D metabolites on the $25(\mathrm{OH})$ D levels, and the susceptibility to MS and to vitamin D supplementation efficacy in MS.

\section{Vitamin D Deficiencies and Ischemic Stroke}

Stroke is the leading cause of significant long-term disability all over the world, and is an enormous source of global disease burden. Ischemic stroke recognizes a heterogeneous etiology, caused by not modifiable risk factors (genetic, age, and sex), and modifiable risk factors, like hypertension, diabetes mellitus (DM), dyslipidemia, sedentary lifestyle, and smoking [125].

Vitamin D deficiency is found to increase the risk of vascular disease and ischemic stroke in healthy subjects; the risk is higher for ischemic stroke than for hemorrhagic ones. Moreover, vitamin $\mathrm{D}$ deficiency is associated with other contributing factors for ischemic stroke (i.e., hypertension, hyperlipidemia, diabetes mellitus, and ischemic heart disease). In a stroke, vitamin D deficiency might relate with higher disease severity and adverse outcomes, including death; moreover, hypovitaminosis $\mathrm{D}$ is independently associated with larger ischemic infarct volume [126]; finally, vitamin D deficiency is related to slower recovery after stroke. Moreover, recently, it has been found $[125,126]$ that lower concentrations of $25(\mathrm{OH}) \mathrm{D}$ were associated with a higher risk of incident stroke in models adjusted for age, race, age and race interaction, and sex. The magnitude and strength of the associations were unchanged after the adjustment for the season of blood draw; systolic blood pressure; BMI; diabetes; current cigarette smoking; atrial fibrillation; and use of anti-hypertensive medications, aspirin, and statins. In their work, no statistically significant differences in the association of lower 25(OH) D with a higher risk of incident stroke were observed in black subjects when compared with white subjects. Vitamin D can inhibit the development of thrombosis, which may provide a rational explanation for the relationship between vitamin D and ischemic stroke. Nevertheless, vitamin D might induce hemorrhagic stroke through other mechanisms, such as inflammation and endothelium shear stress. Even less is known regarding the relationship between vitamin D deficiency and other cerebrovascular diseases, like vessel dissection. Vianello et al. [127] reported that in acute aortic dissection (AAD), hypovitaminosis $\mathrm{D}$ is not associated with changes in bone-related metabolic pathways, but is inversely related to osteocalcin, which could be an exciting molecule that is able to mediate the effect of an inadequate 25(OH) D level at vascular level.

Moderate to strong associations between lower serum 25(OH)D concentrations and stroke were identified in different analytic approaches, even after controlling for traditional demographic and lifestyle covariates. Such associations were most evident among young females, younger than 50 years. The mechanisms behind the associations between vitamin D and cerebrovascular and cardiologic profiles have been widely examined in both animal and human studies. Accumulating evidence has 
shown adverse regulatory effects of vitamin D on the renin-angiotensin system. Renin expression was significantly increased among the vitamin D receptor knockout mice and suppressed among the wild-type mice after being injected with $1,25(\mathrm{OH})_{2} \mathrm{D}$. The treatment of vitamin $\mathrm{D}$ in rats may lead to increased endothelium-dependent vascular relaxation and the inhibition of vascular smooth muscle cell growth and proliferation. Vitamin D supplementation in human subjects may contribute to improved insulin sensitivity and beta-cell function, as well as lower levels of inflammatory markers [128-130].

Moreover, vitamin D deficiency has been shown in several pathologies related to higher incidence of stroke. Shah Sanket et al. reported that a vitamin D deficiency was observed in a significant number of patients with chronic obstructive pulmonary disease (COPD), and in more than half of the study subjects there is an increasing frequency across the combined COPD class of cardiovascular and cerebrovascular disease [130]. Moreover, the stroke patients with enough vitamin D had more favorable outcomes, including improved muscle strength and bone density. Manouchehri et al. [131] showed that a vitamin D deficiency had an increased risk of ischemic stroke by nearly seven-fold compared to the controls. They reported a 13-fold increase in the risk of large vessel stroke, and a 4.37-folded increase for the small vessel stroke was observed. The risk of stroke increases with a concomitant deficit of vitamin D, vitamin B12, and homocysteine. Serum homocysteine, vitamin B12, and vitamin D levels are associated with baseline first-ever stroke severity, but also contribute, to some extent, to its prognosis in the early period after stroke. The early detection and management of these laboratory parameters may contribute both to primary and to secondary stroke prevention. Hyperhomocysteinemia increases the likelihood of stroke and is mostly dependent on folic acid (vitamin B9), vitamin B12, and vitamin B6 serum levels. Vitamin B12 deficiency can be detected in $10-40 \%$ of the general population and may contribute to stroke and cognitive decline. The status of homocysteine, vitamin B12, and vitamin D can go further to assess the importance of these correctable factors during the functional recovery after stroke.

The patients with a low level of serum vitamin $\mathrm{D}$ at the onset of the stroke showed more severe disability [126]. Qiu et al. [132] also reported a strict association between lower serum levels of 25(OH) $\mathrm{D}$, and the stroke recurrence and stroke mortality at 24 months. Also, the inverse association between serum $25(\mathrm{OH}) \mathrm{D}$ levels and functional outcome in patients with acute ischemic stroke had been reported. Mortality in stroke patients is higher for those subjects $<75$ years old with a low serum $25(\mathrm{OH}) \mathrm{D}$ level at stroke onset [133-135]. Few studies have also reported vitamin D deficiency after a stroke. The mean level of $25(\mathrm{OH}) \mathrm{D}$ was lower in the subacute and chronic patients than in the healthy controls; furthermore, the level of $25(\mathrm{OH}) \mathrm{D}$ was lower in the patients with a longer duration of illness after stroke, for one month. These data suggest that it might be explained by an exhaustion of vitamin D, stored before stroke onset, and insufficient synthesis after stroke. Finally, the patients with an independent gait have higher levels of vitamin D than the immobilized patients. Restricted outdoor activity may have affected the synthesis of vitamin $\mathrm{D}$ after the stroke and resulted in a vitamin D deficiency.

The pathophysiology of stroke is quite complex and still not completely understood. Cerebral ischemic damage is due to the activation of several inflammatory events, including the infiltration of circulating immune cells and the activation of microglia, astrocytes, and endothelial cells [136]. In stroke individuals, the mechanism involved in vessel disease, mediated by a vitamin $\mathrm{D}$ deficit, might consist of a release of atherogenic pro-inflammatory cytokines, which foster atherosclerotic vascular changes and might induce plaque instability $[137,138]$. Vitamin D plays an additional role for the regulation of the inflammation process, through prostaglandin inhibition, reduction of mitogen-activated protein kinase (MAPK), and by reducing the expression of the nuclear factor kappa B (NF- $\mathrm{kB})$ pathways [41,139]. Moreover, the down-regulation of pro-inflammatory cytokines, such as tumor necrosis factor (TNF)- $\alpha$, interleukin (IL)-6, IL-12, and interferon (IFN)- $\gamma$, and the up-regulation of anti-inflammatory T regulatory (Treg) and Th2 cells and their cytokines have been reported [140,141]. Thus, the deficit of vitamin D is responsible for endothelial dysfunction [142] and is considered an independent risk factor for the occurrence of acute ischemic stroke $[143,144]$. 
As previously reported, VDD is strictly associated with higher levels of high sensitivity C-reactive protein (hsCRP), remarking the anti-inflammatory activities of vitamin $\mathrm{D}$, including the inhibition of IL-6 synthesis by monocytes. CRP acts on endothelial cells inducing tissue factor expression, and promotes smooth muscle and endothelial cell proliferation [145]. Moreover, CRP increases the plasminogen activator inhibitor-1 expression [146] and induces several inflammatory genes via NF- $\mathrm{kB}$ activation in human endothelial cells [147]. Usually, vitamin D deficiency in stroke patients preceded stroke, and the prevalence of vitamin D deficiency is more evident in stroke patients than general medical patients. On the other hand, vitamin $\mathrm{D}$ supplementation in post-stroke patients may play a role in the prevention of recurrent stroke and improves the functional outcome after stroke [147-150].

Zhao-Nan Wei reported that a vitamin D deficiency is associated with a 3.2-fold increased risk of poor functional outcome events. The adjustment for established cardiovascular risk factors, including glucose level, age, and National Institute of Health Stroke Scale (NIHSS) score, did not attenuate this association. For the vitamin D deficiency, the adjusted risk of mortality increased by $290 \%$ [151]. A high dose oral vitamin D supplementation produced a short-term improvement in the endothelial function in stroke patients, with a better management of blood hypertension. Moreover, a possible cardiovascular protective role of vitamin D has been proposed, in reducing the mortality risk in patients with renal failure.

A meta-analysis of 50 RCTs of supplemental vitamin D, administered for a median of two years, involving predominantly senior women who were mainly in institutions and dependent care, showed that vitamin D decreased mortality [152]. Moreover, vitamin D3 (cholecalciferol) has been shown to decrease mortality significantly. Gupta et al. [152], in a randomized controlled open-label trial, found that patients with acute ischaemic stroke that received vitamin $\mathrm{D}$ and calcium supplementation, along with the usual care, compared with those receiving usual care alone, presented a higher probability of survival, achieving a better outcome at six months compared to the controls [153]. Concerning stroke, the VITamin D and Omega-3 triaL (VITAL) studied the effect of supplementation on the total cancer and major cardiovascular events (a composite of myocardial stroke, and death due to cardiovascular events), thus reporting significant effects only on a reduction of bone fractures [154,155]. Similarly, the benefit of vitamin D supplementation for stroke-related depressive symptoms is still being debated [156]. If vitamin D contributes to post-stroke recovery by pathophysiological mechanisms that should still be elucidated (some could be related to a reduction in the volume of the cerebral infarct and to neuroprotective properties), vitamin D supplementation could bring the hope of a benefit that is not known yet.

In summary, the precise relationship between vitamin D and stroke is still unclear, a revision of the data suggests that vitamin D status is associated with ischemic stroke and with the injury volume. The vitamin D levels should be measured in all stroke patients and should be considered as an independent stroke risk factor. The supplementation of vitamin D could be considered as a fundamental part of stroke therapy, but new studies should be done.

\section{Vitamin D Deficiency and Neurodegenerative Diseases}

Different important studies have implicated amyloid beta accumulation, hyperphosphorylation of tau, oxidative stress, mitochondrial dysfunction, and inflammation as the major responsible factors for a neurodegenerative process, which underlies Alzheimer's disease (AD) [157,158]. Nevertheless, the calcium excitotoxic hypothesis and glutamate currents theories can support and amplify the Alzheimer's cascade of events [159]. Moreover, many doubts still merge, especially for sporadic AD cases pathogenesis. It has been established that the etiology of the sporadic AD might involve multiple gene-environment relationships, and probably many epigenetic mechanisms $[158,160]$. The most debated aspects are those concerning the reasons for Abeta accumulation and the tauopathy consequences in the aging brain being seriously possible, and the relationship between their accumulation and various environmental risk factors, which the brain gathers throughout its life. Epigenetic modifications can act as first hits, with a consequence that remains latent for many years, until a second hit (probably determined by metabolic factors, i.e., altered nutrition, pro-inflammatory 
cytokines, and aging by itself) can promote the degenerative progression [161]. As a result of these premises, VDR, the major effector of vitamin D, polymorphisms have been studied in AD [162]. It has been demonstrated that there is a link between the altered gene expression of VDR and 1,25MARRS (membrane-associated rapid response steroid-binding); this association endorses the less active employment of vitamin D inside neurons, and lets them be more prone to degeneration [163]. Brewer et al. [163] and confirmed by Thibault et al. [164] recognized that cultured hippocampal cells treated with adequate concentrations of VDH (1-100 nM) were protected against excitotoxic insults, probably because of a modulation of L-type voltage-sensitive calcium channels, whose increase has been documented in hippocampus aged cells [165], and the aged long-term cultured hippocampus cells [166]. VDH down-regulates mRNA expression for different subunits of L-type voltage-sensitive calcium channels. Consequently, VDH has a fundamental role in the homeostasis of calcium-mediated activities [164], such as neuronal death and apoptosis. The VDR ${ }^{-/-}$knock-out model shows a higher sensitivity to neuro-degeneration, with a rapid increase of calcium currents and neural death $[166,167]$. Many different VDR polymorphisms have been described as increasing the susceptibility to AD [168], mainly due to the altered expression of neurotrophins. Genome analyses, transcriptomics, and proteomics have pointed out the role of VDR polymorphism in late-onset AD susceptibility [162]. In fact, even in animal models, vitamin D seems to interfere with cognitive functions, even in other ways, probably through its different polymorphic gene expression of VDR [26]. It seems, for instance, that Bsm I and Taq I altered carriers are more prone to manifest memory and cognitive dysfunctions, as well as a vitamin D defect; on the contrary, the APA-I haplotype is associated with an increased risk of fractures, but not memory alterations [169]. Therefore, in line with Buell and Dawson-Hughes [169], calcium concentrations are not likely to vary in the different haplotypes, indicating a protective effect on the brain, beyond the calcium homeostasis. Thus, in the Alzheimer disease culture models, VDH stimulates the amyloid plaques $[170,171]$, supporting the phagocytosis induced by macrophages of a soluble amyloid beta protein [171,172], and reduces the inflammation response induced by amyloid deposition [21]. Lipopolysaccharide-induced levels of mRNA encoding for macrophage colony stimulating factors and tumor necrosis factors in cultured astrocytes are partially reduced after vitamin D treatment [21]. Additionally, vitamin D has neuroprotective properties against glutamate toxicity [173]. It inhibits the synthesis of inducible nitric oxide synthase and regulates the gamma-glutamyl transpeptidase, fundamental in the metabolism of glutathione [174]. Furthermore, vitamin D enhances the protein phosphatase 2A activity, modulating the redox state, and thus reducing the age-related tau hyperphosphorylation, limiting the cascade of neuronal dying back and the promotions of collateral inflammatory potentiation [175]. To summarize, it seems that vitamin D acts in the brain, through the regulation of NGF and neurotransmitters, regulating calcium homeostasis, promoting anti-inflammatory responses, interfering with amyloid beta metabolism, and implementing a brain oxidative response. On the contrary, clinical practice does not give univocal results. A vitamin D deficit has been widely detected in the frail old population [176,177], and calcium homeostasis is heavily lowered in neurodegenerative pathologies, such as Alzheimer disease $[177,178]$. In a mild cognitive impairment population, not including Alzheimer disease, a low level of vitamin $\mathrm{D}$ was reported [179]. Nevertheless, the vitamin D implementation in clinical practice does not give univocal results. A seven-year follow-up study confirmed that a larger intake of vitamin D is associated with a lower risk of developing AD in normal aging women $[180,181]$. Some recent works have evidenced that the combined effect of vitamin D and docosahexaenoic acid can enhance the neural protection towards the different effects of beta-amyloid deposition [182,183], and a six-month trial determined that the patient obtains better results, with even limited effects, when the memantine was prescribed in association with vitamin $\mathrm{D}$, rather than alone, in the AD patients [182]. On the other hand, two studies showed the opposite results $[183,184]$. Even though many different studies are needed to demonstrate a definite role in the real clinical practice of the supplementation of vitamin $D$, many questions remain without a proper answer, such as: 
1. When should the implementation begin?

2. Is it a possible preventive therapy for reducing the cascade of events of the AD?

3. Should it be considered as one of the multifactor agents (along with folate, vitamin B12, and antioxidant substances) that can procrastinate the AD second hit process?

\subsection{Vascular Dementia}

Emergent evidence from experimental and clinical studies suggests that vitamin D may be a causal effect for neurodegeneration, concerning vascular dementia, supporting the underlying/concomitant atherosclerotic pathology [185]. Some studies link the vitamin defect to an increased risk of hypertension, diabetes, congestive heart failure, myocardial infarction, and stroke [186]. Moreover, some very recent studies link it to small vessel disease and vascular dementia as well $[187,188]$. The vitamin D receptors are hugely expressed by the endothelial cells, and their activation induces the promotion towards the maturation of immature cells, via Vasoactive Endothelium derived Growth Factor (VEGF) [189]. The vitamin D receptor gene is up-regulated during inflammation in endothelial cells [190-192], and the vitamin D analogs protect against advanced glycation products derived insults [193]. Enriched vitamin D diet models promote an anti-lymphoproliferative effect on the endothelium and a diminished response to inflammatory cytokines [194,195]. Moreover, as previously described, vitamin D regulates the expression of 74 genes and 36 proteins, connected with the correct development of the cytoskeleton and exerting a regulation on post-transcriptional controls for L-type voltage-sensitive calcium channels $[196,197]$. All of the effects of vitamin D on the vascular system link it to vascular dementia in many different ways, such as: epidemiological [198], based on vascular pressure control [191], based on biological properties of vitamin D, above described [199], or simply considering vitamin D deficiency as a risk-modifiable factor $[170,200,201]$. It seems quite interesting that the three works that link the vitamin D defect to small vessel disease-related dementia $[188,189]$ stand on two axiomatic biological properties, the anti-oxidative capacity of vitamin D (therefore a loss of protection against Reactive Oxygene Species (ROS), whenever it lacks), and the control of the smooth vessel, which is fundamental for auto-regulation in brain circulation. Many studies evidenced an excess of superoxide by Nicotinamide Adenine Dinucleotide Phosphate Hydrogen (NADPH) oxidase in small vessel disease [202]. This causes an increase of ROS, indirectly evidenced by a hyper-expression of the Nitrogen Oxide (NOX) 2 and NOX 4 oxidase isoforms [202,203]; ROS induced damage is one of the triggers for apoptosis. In vitro, vitamin D down-regulates the activity of NF-KB activity [204] and stimulates the anti-inflammatory cytokines [205]. Additionally, vitamin D-binding proteins are more evident in proximity to endothelium injury [206], inhibiting the expression of Matrix Metalloproteinase (MMP-2, MMP-9), and of the endothelium growth factor [207]; they probably diminish the activity of the platelet-derived growth factor, conversely up-regulating thrombomodulin [208,209]. The second study, entirely dedicated to small vessel disease and vitamin D [198], lights some shadows in a fascinating problem; it presents a public association between bone small vessel disease and osteoporosis. Authors hypothesize a common method of alteration, in the peripheral autonomous nervous system, which deteriorates the small-bone vessels as well as brain vessels [210]. The first and the third study on the topic $[188,189]$, starting from two different perspectives have some common points. Chung et al. [188] demonstrated that vitamin D is inversely associated with lacunes, white matter hyperintensities, and deep micro-bleeding in the deep white matter, not elsewhere, suggesting a high impact on small vessel disease. Moretti et al. [198] hypothesized that vitamin D might act on the altered control of cerebral blood flow (CBF) [211,212] and in the distorted neurovascular coupling system $[213,214]$, both heavily impaired in small vessel dementia. Intracerebral calcium, intimately regulated by vitamin $\mathrm{D}$, interferes with the vessel activation. Vessel relaxation is heavily influenced by ATP-sensitive potassium channels (delayed rectifier and inward rectifier potassium channel), but also by calcium-activated potassium channels $[215,216]$. Mediated by cAMP, calcium-activated-potassium channels seem to be involved in the negative "feedback system to regulate vascular tone" [215]. It seems that in atherosclerosis models, there is a major impairment of calcium-activated potassium 
channels in mainstream vessels [215]. On the other hand, the neurovascular coupling system (smooth vascular cells, neurons, and astrocytes) seems to be intimately regulated by vitamin $\mathrm{D}$, which is determinant for the glutamate release. Glutamate passes from the synapse, activating Nicotinamide Adenine Dinucleotide Phosphate Hydrogen- Receptors (NMDAR) in the neurons and metabotropic glutamate receptors in the astrocytes [214]. Moreover, by interfering with the calcium influx, vitamin D indirectly mediates the neural nitric oxide synthase. NO activates phospholipase A2 in the astrocytes, enabling the prostaglandin cascade, which widens the arteries. The presence of vitamin $\mathrm{D}$ increases, moreover, acetylcholine, and VIP, which potentiates the mechanism. Low levels of vitamin D might, therefore, interfere with smooth cells control, with $\mathrm{NO}$ and neuropeptides synthesis, and with defective neurovascular coupling, leading to some aspects of small vessel disease. There are very few the studies concerning vitamin D supplementation in vascular dementia.

\subsection{Parkinson Disease (PD)}

A significant concentration of vitamin D receptors were found in the hippocampus, in the prefrontal cortex-brain, and the substantia nigra [217]. There is evidence of low levels of vitamin D and increased bone turnover markers, such as bone alkaline phosphatase, compared to the controls [218]. All of the non-genomic roles of vitamin D are evident in the PD models [219,220]; there is an active regulation of calcium inside the neurons and astrocytes; there is a substantial regulation of L-type voltage-sensitive calcium channels; it has been described an induction and promotion of NGF and other growth factors, with a down-regulation of MMP and other inflammatory activity, such as prostaglandins and COX-2 activity; and there is also a reduction of oxidative stress, by interfering with NO production by lipopolysaccharide-stimulated macrophages [221]. There are many data that even relate the vitamin-related genomic factors to PD progression. Increased levels of MHC class II expressions were detected in the monocytes of the cerebrospinal fluid of the PD patients [222], together with Human Leukocyte Antigen Complex- antigen D related (HLA-DR) positive reactive microglia, found in the substantia nigra and in nigro-striatal tract of PD patients [223]. Recent evidence demonstrated that vitamin D suppresses the MHC class II antigens [224] and IFN-gamma induced HLA-DR antigen expression in human cells [225]. Additionally, Cytochrome P450 (CYP), and in particular, CYP2D6, which has a polymorphic expression, and which is expressed in neurons and the gut, has a different expression in PD patients; here, it has been found preponderantly as the CYP2D6*4 allele [226]. CYP2D6 acts as a 25-hydroxylase, which can convert vitamin D3 into 25OHD, being the key enzyme to determine a deficiency of vitamin D. In the mouse MPTP treated model (inducing PD phenotype), Singh et al. [225] reported the stable expression of the animal ortholog of CYP2D6, CYP2D22. Very interestingly, the CYP2D loci are located on chromosome 22, where many genes related to PD are segregated $[227,228]$. It seems surprising that the deletion of chromosome 22q11 was reported to be associated with PD [228], but also with the reduced serum calcium and a reduced level of vitamin D [228].

Moreover, there are three more links between vitamin D and PD. The first one is the so-called Sp1 transcription factor. The protein encoded by this gene is a zinc finger transcription factor that binds to the guanine-cytosine (GC)-rich motifs of many promoters. The encoded protein is involved in many cellular processes, including cell differentiation, cell growth, apoptosis, immune responses, response to DNA damage, and chromatin remodeling. Post-translational modifications, such as phosphorylation, acetylation, glycosylation, and proteolytic processing, significantly affect the activity of this protein, which can be an activator or a repressor. The Sp1 transcriptions factor is a DNA binding protein that mediates the accurate response to oxidative stress in neurons $[229,230]$, controls the expression of the dopamine transporter gene, and of the dopamine receptor gene [231,232]. The link between vitamin D and Sp1 is represented by the fact that many hormones have different binding sites for the transcription factors for Sp1. In fact, two vitamin D-responsive elements (which act by inducing the expression of CYP24 genes, previously described, and 25-OHD-24 hydroxylase) are helped by the 
synergic activation of Sp1 [229,233]. As Sp1 controls the expression of the dopamine transporter gene within the dopaminergic neurons, VDR conditions and promotes Sp1 trigger gene expression.

The second genomic link factor between vitamin D and PD is represented by Heme oxygenase, a stress protein with anti-oxidant properties. In the healthy brain, its expression is limited to neuroglia [234], whereas it is overexpressed in PD brains, but not in AD patients [235]. In PD brains, Heme oxygenase 1 is overexpressed in astrocytes within the substantia nigra and the deteriorated dopaminergic neurons [236]. Entirely unpredicted, calcitriol seems able to delay the effect of Heme oxygenase, reducing the glial fibrillary immunoreactivity [237].

Finally, vitamin D seems to interfere with the activity of Poly (ADP-Ribose) Polymerase-1, also called PARP1. It is a stress protein, which can, however, promote neuronal death. In fact, there is an overexpression of PARP1 in the substantia nigra of PD patients [238]; increased levels of vitamin D down regulate the PARP-1 expression, probably mediated by a diminishment of microglial activation [239]. All of these aspects considered in the clinical trials on vitamin D supplementation in Parkinson's disease have been carried out. Although some data demonstrated that low levels of vitamin D might influence the speed of the disease, the supplementation of vitamin D did not modify the disease outcomes. That conclusion probably lies in a clinical time of supplementation, far from the initial ones of labs models.

\section{Conclusions}

Accumulating evidence shows that vitamin D is important for accurate brain functioning. Moreover, it is important to note that many important neurological diseases are related to low levels of vitamin D. These expressions are supported by in vivo, in vitro, and in human trials. Unfortunately, at the moment, the results for its supplementation in neurological disorders, in particular concerning data on vitamin supplementation and their progression or eventual real clinical benefits are inconclusive. As such, there is a strong need for randomized clinical trials on neurodegenerative patients and vitamin D supplementation, to optimize time, efficacy, and appropriate monitoring [240,241].

It should be said that vitamin $\mathrm{D}$ supplementation might be safe and inexpensive. However, physicians may be uncomfortable recommending larger doses of vitamin D, because of its potential toxicity. The rarity of reports of vitamin D toxicity can be explained, in part, by the kidney's ability to limit the production of active calcitriol. Increased calcitriol levels inhibit parathormone (PTH), causing the calcitriol production in the kidney to decrease. The renal 24-hydroxylase activity further limits the availability of calcitriol by creating inert metabolites of both calcitriol (1,24,25-trihydroxyvitamin D) and calcidiol (24,25-dihydroxyvitamin D). The 24-hydroxylase gene is under the transcriptional control of calcitriol, thereby providing a tight negative feedback.

Concerning vitamin D replacement, several studies have shown that both vitamin D2 and vitamin D3 are effective in maintaining the serum 25(OH)D levels. Both D2 (ergocalciferol) and D3 (cholecalciferol) are available as dietary supplements, and both appear to be effective. A single dose of 50,000 IU of D2 or D3 produces a similar increase in the total $25(\mathrm{OH}) \mathrm{D}$ concentration, but the apparent longer half-life of $\mathrm{D} 3$ suggests that less frequent dosing may be needed. To replenish the serum $25(\mathrm{OH}) \mathrm{D}$ levels in persons with a vitamin D deficiency, one cost-effective regimen is oral ergocalciferol at 50,000 IU per week for eight weeks. The optimal time for rechecking the serum levels after being replenished has not been clearly defined, but the goal is to achieve a minimum level of $30 \mathrm{ng}$ per mL.

Special mention is needed for patients who require tube feeding or parenteral nutrition. In those cases, ergocalciferol capsules containing D2 in oil, which can clog the feeding tube, should not be used. Cholecalciferol capsules and tablets contain D3 in powder form and can be used.

New approaches are emerging in vitamin D deficiency. The combined treatment using bisphosphonates and vitamin D has been suspected to be more effective compared with bisphosphonate or vitamin $\mathrm{D}$ alone in the prevention of atherosclerosis. In a recent study, the combination of bisphosphonates and vitamin $D$ has been seen to be safe and effective in systemic lupus erythematosus. Bisphosphonates are expected to inhibit the arterial plaque development and calcification through several mechanisms (mostly 
inducing decreased levels of inflammatory cytokines and matrix metalloproteinases). Bisphosphonates also decrease a variety of mature vascular cells, which migrate into the vessel walls and injure vascular endothelial cells. Moreover, treatment with statins in combination with bisphosphonates has been shown to be more effective in terms of reducing atherosclerotic plaque, compared with either monotherapy in patients with hypercholesterolemia [242,243].

Reading what the literature has reported, it seems that the supplementation of vitamin D might reduce the risks and improve the pathological features in different neurological conditions, but, because of different and unknown reasons, it seems that its supplementation might not be sufficient to change the outcomes and the disease phenotype. All of this considered, there is a strong need for further research in this field, even to account for the best quality of vitamin implementation.

Author Contributions: R.M. designed the study, supervised the entire project and directly studied neurodegeneration and vitamin D; P.C. revised the manuscript and wrote the vascular paragraphs; M.E.M. wrote the multiple sclerosis paragraph.

Funding: This Research received no external funding.

Acknowledgments: The authors thank Hellen Davies, for her precious help and assistance.

Conflicts of Interest: The authors declare no conflict of interest.

\section{References}

1. Holick, M.F. Vitamin D Deficiency. N. Engl. J. Med. 2007, 357, 266-281. [CrossRef] [PubMed]

2. Arabi, A.; El Rassi, R.; El-Hajj Fuleihan, G. Hypovitaminosis D in developing countries-prevalence, risk factors and outcomes. Nat. Rev. Endocrinol. 2010, 6, 550-561. [CrossRef] [PubMed]

3. Prentice, A.; Schoenmakers, I.; Jones, K.; Jarjou, L.A.; Goldberg, G. Vitamin D Deficiency and Its Health Consequences in Africa. Clin. Rev. Bone Miner. Metab. 2009, 7, 94-106. [CrossRef] [PubMed]

4. Ross, A.C.; Manson, J.E.; Abrams, S.A.; Aloia, J.F.; Brannon, P.M.; Clinton, S.K.; Durazo-Arvizu, R.A.; Gallagher, J.C.; Gallo, R.L.; Jones, G.; et al. The 2011 report on dietary reference intakes for calcium and vitamin D from the Institute of Medicine: What clinicians need to know. J. Clin. Endocrinol. Metab. 2011, 96, 53-58. [CrossRef] [PubMed]

5. Di Somma, C.; Scarano, E.; Barrea, C.; Zhukouskay, V.V.; Savastano, S.; Mele, C.; Scacchi, M.; Aimaretti, G.; Colao, A.; Marzullo, P. Vitamin D and neurological disease: An endocrine view. Int. J. Mol. Sci. 2017, 18, 2482. [CrossRef] [PubMed]

6. Yang, L.; Ma, J.; Zhang, X.; Fan, Y.; Wang, L. Protective role of the vitamin D receptor. Cell. Immunol. 2012, 279, 160-166. [CrossRef] [PubMed]

7. Gominak, S.C. Vitamin D deficiency changes the intestinal microbiome reducing B vitamin production in the gut. The resulting lack of pantothenic acid adversely affects the immune system, producing a "pro-inflammatory" state associated with atherosclerosis and autoimmunity. Med. Hypotheses 2016, 94, 103-107. [PubMed]

8. Luthold, R.V.; Fernandes, G.R.; Franco-de-Moraes, A.C.; Folchetti, L.G.; Ferreira, S.R. Sandra Roberta G Ferreira. Gut microbiota interactions with the immunomodulatory role of vitamin $\mathrm{D}$ in normal individuals. Metabolism 2017, 69, 76-86. [CrossRef] [PubMed]

9. Tremlett, H.; Bauer, K.C.; Appel-Cresswell, S.; Finlay, B.B.; Waubant, E. The gut microbiome in human neurological disease: A review. Ann. Neurol. 2017, 81, 369-382. [CrossRef] [PubMed]

10. Holick, M.F.; Chen, T.C. Vitamin D deficiency: A worldwide problem, with health consequences. Am. J. Clin. Nutr. 2008, 87, 1080S-1086S. [CrossRef] [PubMed]

11. DeLuca, G.C.; Kimball, S.M.; Kolasinski, J.; Ramagopalan, S.V.; Ebers, G.C. Review: The role of vitamin D in nervous system health and disease. Neuropathol. Appl. Neurobiol. 2013, 39, 458-484. [CrossRef] [PubMed]

12. Wang, L.; Song, Y.; Manson, J.E.; Pilz, S.; März, W.; Michaëlsson, K.; Lundqvist, A.; Jassal, S.K.; Barrett-Connor, E.; Zhang, C.; et al. Circulating 25-hydroxy-vitamin D and risk of cardiovascular disease: A meta-analysis of prospective studies. Circ. Cardiovasc. Qual. Outcomes 2012, 5, 819-829. [CrossRef] [PubMed]

13. Brondum-Jacobsen, P.; Nordestgaard, B.G.; Schnohr, P.; Benn, M. 25-Hydroxyvitamin D and symptomatic ischemic stroke: An original study and meta-analysis. Ann. Neurol. 2013, 73, 38-47. [CrossRef] [PubMed] 
14. Chowdhury, R.; Stevens, S.; Ward, H.; Chowdhury, S.; Sajjad, A.; Franco, O.H. Circulating vitamin D, calcium and risk of cerebrovascular disease: A systematic review and meta-analysis. Eur. J. Epidemiol. 2012, 27, 581-591. [CrossRef] [PubMed]

15. Fleet, J.C. Rapid, membrane-initiated actions of 1,25 dihydroxyvitamin D: What are they and what do they mean? J. Nutr. 2004, 134, 3215-3218. [CrossRef] [PubMed]

16. Veenstra, T.D.; Prufer, K.; Koenigsberger, C.; Brimijoin, S.W.; Grande, J.P.; Kumar, R. 1,25-Dihydroxyvitamin D3 receptors in the central nervous system of the rat embryo. Brain Res. 2005, 804, 193-205. [CrossRef]

17. Annweiler, C.; Montero-Odasso, M.; Hachinski, V.; Seshadri, S.; Bartha, R.; Beauchet, O. Vitamin D concentration and lateral cerebral ventricle volume in older adults. Mol. Nutr. Food Res. 2013, 57, $267-276$. [CrossRef] [PubMed]

18. Brown, J.I.; Bianco, J.; McGrath, J.; Eyles, D.W. 1,25-Dihydroxyvitamin D3 induces nerve growth factor, promotes neurite outgrowth and inhibits mitosis in embryonic rat hippocampal neurons. Neurosci. Lett. 2003, 343, 139-143. [CrossRef]

19. Baksi, S.N.; Hughes, M.J. Chronic vitamin D deficiency in the weanling rat alters catecholamine metabolism in the cortex. Brain Res. 1982, 242, 387-390. [CrossRef]

20. Puchacz, E.; Stumpf, W.E.; Stachowiak, E.K.; Stachowiak, M.K. Vitamin D increases expression of the tyrosine hydroxylase gene in adrenal medullary cells. Mol. Brain Res. 1996, 36, 193-196. [CrossRef]

21. Garcion, E.; Wion-Barbot, N.; Montero-Menei, C.N.; Berger, F.; Wion, D. New clues about vitamin D functions in the nervous system. Trends Endocrinol. Metab. 2002, 13, 100-105. [CrossRef]

22. Minasyan, A.; Keisala, T.; Lou, Y.R.; Kalueff, A.V.; Tuohimaa, P. Neophobia, sensory and cognitive functions, and hedonic responses in vitamin D receptor mutant mice. J. Steroid Biochem. Mol. Biol. 2007, 104, $274-280$. [CrossRef] [PubMed]

23. Burne, T.H.J.; Johnston, A.N.B.; McGrath, J.J.; MacKay-Sim, A. Swimming behavior and post-swimming activity in Vitamin D receptor knockout mice. Brain Res. Bull. 2006, 69, 74-78. [CrossRef] [PubMed]

24. Gezen-Ak, D.; Dursun, E.; Yilmazer, S. The effects of vitamin D receptor silencing on the expression of LVSCC-A1C and LVSCC-A1D and the release of NGF in cortical neurons. PLoS ONE 2011, 6, e17553. [CrossRef] [PubMed]

25. Eyles, D.W.; Liu, P.Y.; Josh, P.; Cui, X. Intracellular distribution of the of the vitamin D receptor in the brain. A comparison with classical target tissues and redistribution with development. Neuroscience 2014, 268, 1-9. [CrossRef] [PubMed]

26. Becker, A.; Eyles, D.W.; McGarth, J.J.; Grecksc, G. Transient prenatal vitamin D deficiency is associated with subtle alterations in learning and memory functions in adult rats. Behav. Brain Res. 2005, 161, 306-312. [CrossRef] [PubMed]

27. Byrne, J.H.; Voogt, M.; Turner, K.M.; Eyles, D.W.; McGrath, J.J.; Burne, T.H. The impact of adult vitamin $\mathrm{D}$ deficiency on behavior and brain function in male Sprague-Dawley rats. PLoS ONE 2013, 8, e71593. [CrossRef] [PubMed]

28. Achiron, A.; Gurevich, M.; Magalashvili, D.; Kishner, I.; Dolev, M.; Mandel, M. Understanding autoimmune mechanisms in multiple sclerosis using gene expression microarrays: Treatment effect and cytokine-related pathways. Clin. Dev. Immunol. 2004, 11, 299-305. [CrossRef] [PubMed]

29. Bhalla, A.K.; Amento, E.P.; Clemens, T.L.; Holick, M.F.; Krane, S.M. Specific high-affinity receptors for 1,25-dihydroxyvitamin D3 in human peripheral blood mononuclear cells: Presence in monocytes and induction in T lymphocytes following activation. J. Clin. Endocrinol. Metab. 1983, 57, 1308-1310. [CrossRef] [PubMed]

30. Veldman, C.M.; Cantorna, M.T.; DeLuca, H.F. Expression of 1,25-dihydroxyvitamin D3 receptor in the immune system. Arch. Biochem. Biophys. 2000, 374, 334-338. [CrossRef] [PubMed]

31. Chun, R.F.; Liu, P.T.; Modlin, R.L.; Adams, J.S.; Hewison, M. Impact of vitamin D on immune function: Lessons learned from genome-wide analysis. Front. Physiol. 2014, 5, 151. [CrossRef] [PubMed]

32. Gottfried, E.; Rehli, M.; Hahn, J.; Holler, E.; Andreesen, R.; Kreutz, M. Monocyte-derived cells express CYP27A1 and convert vitamin D3 into its active metab-olite. Biochem. Biophys. Res. Commun. 2006, 349, 209-213. [CrossRef] [PubMed]

33. Mora, J.; Iwata, M.; von Andrian, U. Vitamin effects on the immune system: Vitamins A and D take centre stage. Nat. Rev. Immunol. 2008, 8, 685-698. [CrossRef] [PubMed]

34. Lips, P. Vitamin D physiology. Prog. Biophys. Mol. Biol. 2006, 92, 4-8. [CrossRef] [PubMed] 
35. Martineau, A.R.; Wilkinson, K.A.; Newton, S.M.; Floto, R.A.; Norman, A.W.; Skolimowska, K.; Davidson, R.N.; Sørensen, O.E.; Kampmann, B.; Griffiths, C.J.; et al. IFN-gamma- and TNF-independent vitamin D-inducible human suppression of mycobacteria: The role of cathelicidin LL-37. J. Immunol. 2007, 178, 7190-7198. [CrossRef] [PubMed]

36. Penna, G.; Adorini, L. 1 Alpha, 25-dihydroxyvitamin D3 inhibits differentiation, maturation, activation, and survival of dendritic cells leading to impaired alloreactive T cell activation. J. Immunol. 2000, 164, 2405-2411. [CrossRef] [PubMed]

37. Garcion, E.; Nataf, S.; Berod, A.; Darcy, F.; Brachet, P. 1,25-Dihydroxyvitamin D3 inhibits the expression of inducible nitric oxide synthase in rat central nervous system during experimental allergic encephalomyelitis. Brain Res. Mol. Brain Res. 1997, 45, 255-267. [CrossRef]

38. Yu, S.; Cantorna, M.T. The vitamin D receptor is required for iNKT cell development. Proc. Natl. Acad. Sci. USA 2008, 105, 5207-5212. [CrossRef] [PubMed]

39. Van Etten, E.; Mathieu, C. Immunoregulation by 1,25-dihydroxyvitamin D3: Basic concepts. J. Steroid Biochem. Mol. Biol. 2005, 97, 93-101. [CrossRef] [PubMed]

40. Chen, S.; Sims, G.P.; Chen, X.X.; Gu, Y.Y.; Chen, S.; Lipsky, P.E. Modulatory effects of 1,25-dihydroxyvitamin D3 on human B cell differentiation. J. Immunol. 2007, 179, 1634-1647. [CrossRef] [PubMed]

41. Boonstra, A.; Barrat, F.J.; Crain, C.; Heath, V.L.; Savelkoul, H.F.; O'Garra, A. 1 $\alpha, 25-D i h y d r o x y v i t a m i n ~ D 3$ has a direct effect on naive CD4(+) T cells to enhance the development of Th2 cells. J. Immunol. 2001, 167, 4974-4980. [CrossRef] [PubMed]

42. Smolders, J.; Thewissen, M.; Peelen, E.; Menheere, P.; Cohen Tervaert, T.W.; Hupperts, R.; Hupperts, R. Vitamin D status is positively correlated with regulatory $\mathrm{T}$ cell function in patients with multiple sclerosis. PLoS ONE 2009, 4, e6635. [CrossRef] [PubMed]

43. Smolders, J.; Menheere, P.; Thewissen, M.; Peelen, E.; Cohen Tervaert, J.W.; Hupperts, R.; Damoiseaux, J. Regulatory $\mathrm{T}$ cell function correlates with serum 25-hydroxyvitamin D, but not with 1, 25-dihydroxyvita-min $\mathrm{D}$, parathyroid hormone and calcium levels in patients with relapsing remitting multiple sclerosis. J. Steroid Biochem. Mol. Biol. 2010, 121, 243-246. [CrossRef] [PubMed]

44. Burton, J.M.; Kimball, S.; Vieth, R.; Bar-Or, A.; Dosch, H.M.; Cheung, R.; Gagne, D.; D'Souza, C.; Ursell, M.; O'Connor, P. A phase I/II dose-escalation trial of vitamin D3 and calcium in multiple sclerosis. Neurology 2010, 74, 1852-1859. [CrossRef] [PubMed]

45. Mahon, B.D.; Gordon, S.A.; Cruz, J.; Cosman, F.; Cantorna, M.T. Cytokine profile in patients with multiple sclerosis following vitamin D supplementation. J. Neuroimmunol. 2003, 134, 128-132. [CrossRef]

46. Kotter, M.R.; Li, W.W.; Zhao, C.; Franklin, R.J.M. Myelin impairs CNS remyelination by inhibiting oligodendrocyte precursor cell differentiation. J. Neurosci. 2006, 26, 328-332. [CrossRef] [PubMed]

47. Newmark, H.L.; Newmark, J. Vitamin D and Parkinson's disease-A hypothesis. Mov. Disord. 2007, 22, 461-468. [CrossRef] [PubMed]

48. Baas, D.; Prüfer, K.; Ittel, M.E.; Kuchler-Bopp, S.; Labourdette, G.; Sarliève, L.L.; Brachet, P. Rat oligodendrocytes express the vitamin $\mathrm{D}(3)$ receptor and respond to 1,25-dihydroxyvitamin $\mathrm{D}(3)$. Glia 2000, 31, 59-68. [CrossRef]

49. Eyles, D.W.; Smith, S.; Kinobe, R.; Hewison, M.; McGrath, J.J. Distribution of the vitamin D receptor and 1-hydroxylase in human brain. J. Chem. Neuroanat. 2005, 29, 21-30. [CrossRef] [PubMed]

50. Lassmann, H.; Bruck, W.; Lucchinetti, C.; Rodriguez, M. Remyelination in multiple sclerosis. Mult. Scler. 1997, 3, 33-136. [CrossRef] [PubMed]

51. Patrikios, P.; Stadelmann, C.; Kutzelnigg, A.; Rauschka, H.; Schmidbauer, M.; Laursen, H.; Sorensen, P.S.; Brück, W.; Lucchinetti, C.; Lassmann, H. Remyelination is extensive in a subset of multiple sclerosis patients. Brain 2006, 129, 3165-3172. [CrossRef] [PubMed]

52. Bruck, W.; Bitsch, A.; Kolenda, H.; Bruck, Y.; Stiefel, M.; Lassmann, H. Inflammatory central nervous system demyelination: Correlation of magnetic resonance imaging findings with lesion pathology. Neurology 1997, 42, 783-793. [CrossRef] [PubMed]

53. Franklin, R.J.; Ffrench-Constant, C.; Edgar, J.M.; Smith, K.J. Neuroprotection and repair in multiple sclerosis. Nat. Rev. Neurol. 2012, 8, 624-634. [CrossRef] [PubMed]

54. Ludwin, S.K.; Maitland, M. Long-term remyelination fails to reconstitute normal thickness of central myelin sheaths. J. Neurol. Sci. 1984, 64, 193-198. [CrossRef]

55. Hanafy, K.A.; Sloane, J.A. Regulation of remyelination in multiple sclerosis. FEBS Lett. 2011, 585, 3821-3828. [CrossRef] [PubMed] 
56. Pluchino, S.; Zanotti, L.; Brini, E.; Ferrari, S.; Martino, G. Regeneration and repair in multiple sclerosis: The role of cell transplantation. Neurosci. Lett. 2009, 456, 101-106. [CrossRef] [PubMed]

57. Fancy, S.P.; Kotter, M.R.; Harrington, E.P.; Huang, J.K.; Zhao, C.; Rowitch, D.H.; Franklin, R.J. Overcoming remyelination failure in multiple sclerosis and other myelin disorders. Exp. Neurol. 2010, 225, 18-23. [CrossRef] [PubMed]

58. De la Fuente, A.G.; Errea, O.; van Wijngaarden, P.; Gonzalez, G.A.; Kerninon, C.; Jarjour, A.A.; Lewis, H.J.; Jones, C.A.; Nait-Oumesmar, B.; Zhao, C.; et al. Vitamin D receptor-retinoid X receptor heterodimer signaling regulates oligodendrocyte progenitor cell differentiation. J. Cell Biol. 2015, 211, 975-985. [CrossRef] [PubMed]

59. Shirazi, H.A.; Rasouli, J.; Ciric, B.; Rostami, A.; Zhang, G.X. 1,25-Dihydroxyvitamin D3 enhances neural stem cell proliferation and oligodendrocyte differentiation. Exp. Mol. Pathol. 2015, 98, 240-245. [CrossRef] [PubMed]

60. Ferguson, B.; Matyszak, M.K.; Esiri, M.M.; Perry, V.H. Axonal damage in acute multiple sclerosis lesions. Brain 1997, 120, 393-399. [CrossRef] [PubMed]

61. Hayes, C.E. Vitamin D: A natural inhibitor of multiple sclerosis. Proc. Nutr. Soc. 2000, 59, 531-535. [CrossRef] [PubMed]

62. Swank, R.; Lerstad, O.; Strøm, A.; Backer, J. Multiple Sclerosis in Rural Norway. N. Eng. J. Med. 1952, 246, 721-728. [CrossRef]

63. Simpson, S.; Blizzard, L.; Otahal, P.; van der Mei, I.; Taylor, B. Latitude is significantly associated with the prevalence of multiple sclerosis: A meta-analysis. J. Neurol. Neurosurg. Psychiatry 2011, 82, 1132-1141. [CrossRef] [PubMed]

64. Westlund, K. Distribution and mortality time trend of multiple sclerosis and some other diseases in Norway. Acta Neurol. Scand. 1970, 46, 455-483. [CrossRef] [PubMed]

65. Baarnhielm, M.; Olsson, T.; Alfredsson, L. Fatty fish intake is associated with decreased occurrence of multiple sclerosis. Mult. Scler. 2014, 20, 726-732. [CrossRef] [PubMed]

66. Kurtzke, J.; Beebe, G.; Norman, J. Epidemiology of multiple sclerosis in US veterans: III. Migration and the risk of MIS. Neurology 1985, 35, 672. [CrossRef] [PubMed]

67. Ascherio, A.; Munger, K. Environmental risk factors for multiple sclerosis. Part II: Noninfectious factors. Ann. Neurol. 2007, 61, 504-513. [CrossRef] [PubMed]

68. Ascherio, A.; Munger, K.; Simon, K. Vitamin D and multiple sclerosis. Lancet Neurol. 2010, 9, $599-612$. [CrossRef]

69. Lucas, R.; Ponsonby, A.; Dear, K.; Valery, P.C.; Pender, M.P.; Taylor, B.V.; Kilpatrick, T.J.; Dwyer, T.; Coulthard, A.; Chapman, C.; et al. Sun exposure and vitamin D are independent risk factors for CNS demyelination. Neurology 2011, 76, 540-548. [CrossRef] [PubMed]

70. Norval, M.; Halliday, G.M. The consequences of UV-induced immunosuppression for human health. Photochem. Photobiol. 2011, 87, 965-977. [CrossRef] [PubMed]

71. Munger, K.; Zhang, S.; O’Reilly, E.; Hernán, M.A.; Olek, M.J.; Willett, W.C.; Ascherio, A. Vitamin D intake and incidence of multiple sclerosis. Neurology 2004, 62, 60-65. [CrossRef] [PubMed]

72. Salzer, J.; Hallmans, G.; Nystrom, M.; Stenlund, H.; Wadell, G.; Sundstrom, P. Vitamin D as a protective factor in multiple sclerosis. Neurology 2012, 79, 2140-2145. [CrossRef] [PubMed]

73. Dong, Y.; Pollock, N.; Stallmann-Jorgensen, I.S.; Gutin, B.; Lan, L.; Chen, T.C.; Keeton, D.; Petty, K.; Holick, M.F.; Zhu, H. Low 25-hydroxyvitamin D levels in adolescents: Race, season, adiposity, physical activity, and fitness. Pediatrics 2010, 125, 1104-1111. [CrossRef] [PubMed]

74. Bischof, M.G.; Heinze, G.; Vierhapper, H. Vitamin D status and its relation to age and body mass index. Hormone Res. 2006, 66, 211-215. [CrossRef] [PubMed]

75. Munger, K.L.; Chitnis, T.; Ascherio, A. Body size and risk of MS in two cohorts of US women. Neurology 2009, 73, 1543-1550. [CrossRef] [PubMed]

76. Handel, A.E.; Giovannoni, G.; Ebers, G.C.; Ramagopalan, S.V. Environmental factors and their timing in adult-onset multiple sclerosis. Nat. Rev. Neurol. 2010, 6, 156-166. [CrossRef] [PubMed]

77. Mirzaei, F.; Michels, K.B.; Munger, K.; O’Reilly, E.; Chitnis, T.; Forman, M.R.; Giovannucci, E.; Rosner, B.; Ascherio, A. Gestational vitamin D and the risk of multiple sclerosis in offspring. Ann. Neurol. 2011, 70, 30-40. [CrossRef] [PubMed] 
78. Munger, K.L.; Chitnis, T.; Frazier, A.L.; Giovannucci, E.; Spiegelman, D.; Ascherio, A. Dietary intake of vitamin D during adolescence and risk of multiple sclerosis. J. Neurol. 2011, 258, 479-485. [CrossRef] [PubMed]

79. Dobson, R.; Giovannoni, G.; Ramagopalan, S. The month of birth effect in multiple sclerosis: Systematic review, meta-analysis and effect of latitude. J. Neurol. Neurosurg. Psychiatry 2013, 84, 427-432. [CrossRef] [PubMed]

80. Munger, K.; Aivo, J.; Hongell, K.; Soilu-Hänninen, M.; Surcel, H.; Ascherio, A. Vitamin D status during pregnancy and risk of multiple sclerosis in offspring of women in the Finnish maternity cohort. JAMA Neurol. 2016, 73, 515. [CrossRef] [PubMed]

81. Nielsen, N.; Munger, K.; Stenager, E.; Ascherio, A. Author response: Neonatal vitamin D status and risk of multiple sclerosis: A population-based case-control study. Neurology 2017, 89, 411. [CrossRef] [PubMed]

82. Van der Mei, I.A.F.; Ponsonby, A.-L.; Dwyer, T.; Blizzard, L.; Simmons, R.; Taylor, B.V.; Butzkueven, H.; Kilpatrick, T. Past exposure to sun, skin phenotype, and risk of multiple sclerosis: Case-control study. BMJ 2003, 327, 316. [CrossRef] [PubMed]

83. Alter, M.; Kahana, E.; Loewenson, R. Migration and risk of multiple sclerosis. Neurology 1978, 28, $1089-1093$. [CrossRef] [PubMed]

84. Banwell, B.; Bar-Or, A.; Arnold, D.L.; Sadovnick, D.; Narayanan, S.; McGowan, M.; O’Mahony, J.; Magalhaes, S.; Hanwell, H.; Vieth, R.; et al. Clinical, environmental, and genetic determinants of multiple sclerosis in children with acute demyelination: A prospective national cohort study. Lancet Neurol. 2011, 10, 436-445. [CrossRef]

85. Hanwell, H.; Vieth, R.; Magalhaes, S.; McGowan, M.; Marrie, R.A.; Bar-Or, A.; Sadovnick, A.D.; Arnold, D.; Banwell, B. Vitamin D status as a predictor of MS outcome following an initial paediatric demyelinating event. Mult. Scler. 2009, 15, S40-S41.

86. Orton, S.M.; Herrera, B.M.; Yee, I.M.; Valdar, W.; Ramagopalan, S.V.; Sadovnick, A.D.; Ebers, G.C. Sex ratio of multiple sclerosis in Canada: A longitudinal study. Lancet Neurol. 2006, 5, 932-936. [CrossRef]

87. Islam, T.; Gauderman, W.J.; Cozen, W.; Hamilton, A.S.; Burnett, M.E.; Mack, T.M. Differential twin concordance for multiple sclerosis by latitude of birthplace. Ann. Neurol. 2006, 60, 56-64. [CrossRef] [PubMed]

88. Woolmore, J.A.; Stone, M.; Pye, E.M.; Partridge, J.M.; Boggild, M.; Young, C.; Jones, P.W.; Fryer, A.A.; Hawkins, C.P.; Strange, R.C. Studies of associations between disability in multiple sclerosis, skin type, gender and ultraviolet radiation. Mult. Scler. 2007, 13, 369-375. [CrossRef] [PubMed]

89. Correale, J.; Ysrraelit, M.C.; Gaitan, M.I. Oestrogens and 1,25 dihydroxyvitamin D3 show synergistic effect on multiple sclerosis immunomodulation. Mult. Scler. 2009, 15, S196.

90. Eikelenboom, M.J.; Killestein, J.; Kragt, J.J.; Uitdehaag, B.M.; Polman, C.H. Gender differences in multiple sclerosis: Cytokines and vitamin D. J. Neurol. Sci. 2009, 286, 40-42. [CrossRef] [PubMed]

91. Nashold, F.E.; Spach, K.M.; Spanier, J.A.; Hayes, C.E. Estrogen controls vitamin D3-mediated resistance to experimental autoimmune encephalomyelitis by controlling vitamin D3 metabolism and receptor expression. J. Immunol. 2009, 183, 3672-3681. [CrossRef] [PubMed]

92. Agnello, L.; Scazzone, C.; Ragonese, P.; Salemi, G.; Lo Sasso, B.; Schillaci, R.; Musso, G.; Bellia, C.; Ciaccio, M. Vitamin D receptor polymorphisms and 25-hydroxyvitamin D in a group of Sicilian multiple sclerosis patients. Neurol. Sci. 2016, 37, 261-267. [CrossRef] [PubMed]

93. Ahn, J.; Yu, K.; Stolzenberg-Solomon, R.; Simon, K.C.; McCullough, M.L.; Gallicchio, L.; Jacobs, E.J.; Ascherio, A.; Helzlsouer, K.; Jacobs, K.B.; et al. Genome-wide association study of circulating vitamin D levels. Hum. Mol. Genet. 2010, 2739-2745, 2739-2745. [CrossRef] [PubMed]

94. Mokry, L.E.; Ross, S.; Ahmad, O.S.; Forgetta, V.; Smith, G.D.; Goltzman, D.; Leong, A.; Greenwood, C.M.; Thanassoulis, G.; Richards, J.B. Vitamin D and Risk of Multiple Sclerosis: A Mendelian Randomization Study. PLoS Med. 2015, 12, e1001866. [CrossRef] [PubMed]

95. Scazzone, C.; Agnello, L.; Ragonese, P.; Lo Sasso, B.; Bellia, C.; Bivona, G.; Schillaci, R.; Salemi, G.; Ciaccio, M. Association of CYP2R1 rs10766197 with MS risk and disease progression. J. Neurosci. Res. 2018, 96, 297-304. [CrossRef] [PubMed]

96. Pihl-Jensen, G.; Frederiksen, J. 25-Hydroxyvitamin D levels in acute monosymptomatic optic neuritis: Relation to clinical severity, paraclinical findings and risk of multiple sclerosis. J. Neurol. 2015, 262, 1646-1654. [CrossRef] [PubMed] 
97. Mowry, E.; Krupp, L.; Milazzo, M.; Chabas, D.; Strober, J.B.; Belman, A.L.; McDonald, J.C.; Oksenberg, J.R.; Bacchetti, P.; Waubant, E. Vitamin D status is associated with relapse rate in pediatric-onset, M.S. Ann. Neurol. 2010, 67, 618-624. [PubMed]

98. Simpson, S.; Taylor, B.; Blizzard, L.; Ponsonby, A.L.; Pittas, F.; Tremlett, H.; Dwyer, T.; Gies, P.; van der Mei, I. Higher 25-hydroxyvitamin D is associated with lower relapse risk in, M.S. Ann. Neurol. 2010, 68, 193-203. [PubMed]

99. Runia, T.; Hop, W.; de Rijke, Y.; Buljevac, D.; Hintzen, R. Lower serum vitamin D levels are associated with a higher relapse risk in multiple sclerosis. Neurology 2012, 79, 261-266. [CrossRef] [PubMed]

100. Martinelli, V.; Dalla Costa, G.; Colombo, B.; Dalla Libera, D.; Rubinacci, A.; Filippi, M.; Furlan, R.; Comi, G. Vitamin D levels and risk of multiple sclerosis in patients with clinically isolated syndromes. Mult. Scler. J. 2013, 20, 147-155. [CrossRef] [PubMed]

101. Kuhle, J.; Disanto, G.; Dobson, R.; Adiutori, R.; Bianchi, L.; Topping, J.; Bestwick, J.P.; Meier, U.C.; Marta, M.; Dalla Costa, G.; et al. Conversion from clinically isolated syndrome to multiple sclerosis: A large multicentre study. Mult. Scler. 2015, 21, 1013-1024. [CrossRef] [PubMed]

102. Embry, A.F.; Snowdon, L.R.; Vieth, R. Vitamin D and seasonal fluctuations of gadolinium-enhancing magnetic resonance imaging lesions in multiple sclerosis. Ann. Neurol. 2000, 48, 271-272. [CrossRef]

103. Mowry, E.; Waubant, E.; McCulloch, C.; Okuda, D.T.; Evangelista, A.A.; Lincoln, R.R.; Gourraud, P.A.; Brenneman, D.; Owen, M.C.; Qualley, P.; et al. Vitamin D status predicts new brain magnetic resonance imaging activity in multiple sclerosis. Ann Neurol. 2012, 72, 234-240. [CrossRef] [PubMed]

104. Ascherio, A.; Munger, K.; White, R.; Köchert, K.; Simon, K.C.; Polman, C.H.; Freedman, M.S.; Hartung, H.P.; Miller, D.H.; Montalbán, X.; et al. Vitamin D as an early predictor of multiple sclerosis activity and progression. JAMA Neurol. 2014, 71, 306-314. [CrossRef] [PubMed]

105. Fitzgerald, K.; Munger, K.; Ko“chert, K.; Arnason, B.G.; Comi, G.; Cook, S.; Goodin, D.S.; Filippi, M.; Hartung, H.P.; Jeffery, D.R.; et al. Association of Vitamin D Levels With multiple sclerosis activity and progression in patients receiving interferon Beta-1b. JAMA Neurol. 2015, 72, 1458. [CrossRef] [PubMed]

106. Stewart, N.; Simpson, S.; van der Mei, I.; Ponsonby, A.L.; Blizzard, L.; Dwyer, T.; Pittas, F.; Eyles, D.; Ko, P.; Taylor, B.V. Interferon-and serum 25-hydroxyvitamin D interact to modulate relapse risk in, M.S. Neurology 2012, 79, 254-260. [CrossRef] [PubMed]

107. Laursen, J.; Søndergaard, H.; Sørensen, P.; Sellebjerg, F.; Oturai, A. Vitamin D supplementation reduces relapse rate in relapsing-remitting multiple sclerosis patients treated with natalizumab. Mult. Scler. Relat. Dis. 2016, 10, 169-173. [CrossRef] [PubMed]

108. Mowry, E.; Pelletier, D.; Gao, Z.; Howell, M.; Zamvil, S.; Waubant, E. Vitamin D in clinically isolated syndrome: Evidence for possible neuroprotection. Eur. J. Neurol. 2015, 23, 327-332. [CrossRef] [PubMed]

109. Auer, D.P.; Schumann, E.M.; Kumpfel, T.; Gossl, C.; Trenkwalder, C. Seasonal fluctuations of gadolinium-enhancing magnetic resonance resonance imaging lesions in multiple sclerosis. Ann. Neurol. 2000, 47, 276-277. [CrossRef]

110. Rovaris, M.; Comi, G.; Sormani, M.P.; Wolinsky, J.S.; Ladkani, D.; Filippi, M. Effects of seasons on magnetic resonance imagingmeasured disease activity in patients with multiple sclerosis. Ann. Neurol. 2001, 49, 415-416. [CrossRef] [PubMed]

111. Killestein, J.; Rep, M.H.; Meilof, J.F.; Adèr, H.J.; Uitdehaag, B.M.; Barkhof, F.; van Lier, R.A.; Polman, C.H. Seasonal variation in immune measurements and MRI markers of disease activity in, M.S. Neurology 2002, 58, 1077-1080. [CrossRef] [PubMed]

112. Smolders, J.; Menheere, P.; Kessels, A.; Damoiseaux, J.; Hupperts, R. Association of vitamin D metabolite levels with relapse rate and disability in multiple sclerosis. Mult. Scler. J. 2008, 14, 1220-1224. [CrossRef] [PubMed]

113. Weinstock-Guttman, B.; Zivadinov, R.; Qu, J.; Cookfair, D.; Bang, E.; Bergsland, N.; Hussein, S.; Cherneva, M.; Willis, L.; et al. Vitamin D metabolites are associated with clinical and MRI outcomes in multiple sclerosis patients. J. Neurol. Neurosurg. Psychiatry 2011, 82, 189-195. [CrossRef] [PubMed]

114. Koven, N.; Cadden, M.; Murali, S.; Ross, M. Vitamin D and long-term memory in multiple sclerosis. Cognit. Behav. Neurol. 2013, 26, 155-160. [CrossRef] [PubMed]

115. Kimball, S.M.; Ursell, M.R.; O'Connor, P.; Vieth, R. Safety of vitamin D3 in adults with multiple sclerosis. Am. J. Clin. Nutr. 2007, 86, 645-651. [CrossRef] [PubMed] 
116. Soilu-Hanninen, M.; Aivo, J.; Lindstro“m, B.; Elovaara, I.; Sumelahti, M.L.; Färkkilä, M.; Tienari, P.; Atula, S.; Sarasoja, T.; Herrala, L.; et al. A randomised, double blind, placebo controlled trial with vitamin D3as an add on treatment to interferon b-1b in patients with multiple sclerosis. J. Neurol. Neurosurg. Psychiatry 2012, 83, 565-571. [CrossRef] [PubMed]

117. Etemadifar, M.; Janghorbani, M. Efficacy of high-dose vitamin D3 supplementation in vitamin D deficient pregnant women with multiple sclerosis: Preliminary findings of a randomized-controlled trial. Iran. J. Neurol. 2015, 14, 67-73. [PubMed]

118. Smolders, J.; Hupperts, R.M.M.; Vieth, R.; Grimaldi, L.M.; Holmoy, T.; Killestein, J.; Rieckmann, P.; Schluep, M.; Vieth, R.; Hostalek, U.; et al. High dose cholecalciferol (vitamin D3) oil as add-on therapy in subjects with relapsing-remitting multiple sclerosis (RRMS) receiving subcutaneous interferon s-1a (scIFNs-1a). ECTRIMS Online Libr. 2016, 16, 147013.

119. Camu, W. Cholecalciferol supplementation in relapsing multiple sclerosis patients treated with subcutaneous interferon beta-1a: A randomized controlled trial. Neurology 2017, 88 (Suppl. 16), S44.004.

120. Darwish, H.; Haddad, R.; Osman, S.; Ghassan, S.; Yamout, B.; Tamim, H.; Khoury, S. Effect of vitamin D replacement on cognition in multiple sclerosis patients. Sci. Rep. 2017, 7, 45926. [CrossRef] [PubMed]

121. Solomon, A.J.; Whitham, R.H. Multiple Sclerosis and Vitamin D: A Review and Recommendations. Curr. Neurol. Neurosci. Rep. 2010, 10, 389-396. [CrossRef] [PubMed]

122. Shoemaker, T.J.; Mowry, E.M. A review of vitamin D supplementation as disease-modifying therapy. Mult. Scler. 2018, 24, 6-11. [CrossRef] [PubMed]

123. Mozaffarian, D.; Benjamin, E.J.; Go, A.S.; Arnett, D.K.; Blaha, M.J.; Cushman, M.; Das, S.R.; de Ferranti, S.; Després, J.P.; Fullerton, H.J.; et al. Heart Disease and Stroke Statistics-2016 Update: A Report from the American Heart Association. Circulation 2016, 133, e38-e360. [CrossRef] [PubMed]

124. Sadovnick, A.D. Genetic background of multiple sclerosis. Autoimmun. Rev. 2012, 11, 163-166. [CrossRef] [PubMed]

125. Daubail, B.; Jacquin, A.; Guilland, J.-C.; Hervieu, M.; Osseby, G.-V.; Rouaud, O.; Giroud, M.; Béjot, Y. Serum 25-hydroxyvitamin D predicts severity and prognosis in stroke patients. Eur. J. Neurol. 2013, 20, 57-61. [CrossRef] [PubMed]

126. Judd, S.E.; Morgan, C.J.; Panwar, B.; Howard, V.J.; Wadley, V.G.; Jenny, N.S.; Kissela, B.M.; Gutiérrez, O.M. Vitamin D deficiency and incident stroke risk in community-living black and white adults. Int. J. Stroke 2016, 11, 93-102. [CrossRef] [PubMed]

127. Vianello, E.; Dozio, E.; Barassi, A.; Tacchini, L.; Lamont, J.; Trimarchi, S.; Marrocco-Trischitta, M.M.; Romanelli, M.C. Vitamin D Deficiency Is Associated with Increased Osteocalcin Levels in Acute Aortic Dissection: A Pilot Study on Elderly Patients. Hindawi Mediat. Inflamm. 2017, 6412531. [CrossRef] [PubMed]

128. Kato, S. The function of vitamin D receptor in vitamin D action. J. Biochem. 2000, 127, 717-722. [CrossRef] [PubMed]

129. Borges, A.C.; Feres, T.; Vianna, L.M.; Therezinha, B.P. Effect of cholecalciferol treatment on the relaxant responses of spontaneously hypertensive rat arteries to acetylcholine. Hypertension 1999, 34, 897-901. [CrossRef] [PubMed]

130. Sanket, S.; Madireddi, J.; Stanley, W.; Sura, P.; Prabhu, M. Relation between Vitamin D Deficiency and Severity of Chronic Obstructive Pulmonary Disease-A Case Control Study. J. Clin. Diagn. Res. 2016, 10, OC16-OC19. [CrossRef] [PubMed]

131. Manouchehri, N.; Vakil-Asadollahi, M.; Zandifar, A.; Rasmani, F.; Saadatnia, M. Vitamin D Status in Small Vessel and Large Vessel Ischemic Stroke Patients: A Case-control Study. Adv. Biomed. Res. 2017, 6, 146. [PubMed]

132. Qiu, H.; Wang, M.; Mi, D.; Zhao, J.; Tu, W.; Liu, Q. Vitamin D Status and the Risk of Recurrent Stroke and Mortality in Ischemic Stroke Patients: Data from a 24-Month Follow-Up Study in China. J. Nutr. Health Aging 2017, 21, 766-771. [CrossRef] [PubMed]

133. Daubail, B.; Jacquin, A.; Guilland, J.-C.; Khoumri, C.; Aboa-Eboulé, C.; Giroud, M.; Béjot, Y. Association between serum concentration of vitamin D and 1-year mortality in stroke patients. Cerebrovasc. Dis. 2014, 37, 364-367. [CrossRef] [PubMed]

134. Alfieri, D.F.; Lehmann, M.F.; Oliveira, S.R.; Flauzino, T.; Delongui, F.; de Araújo, M.C.; Dichi, I.; Delfino, V.D.; Mezzaroba, L.; Simão, A.N.; et al. Vitamin D deficiency is associated with acute ischemic stroke, C-reactive protein, and short-term outcome. Metab. Brain Dis. 2017, 32, 493-502. [CrossRef] [PubMed] 
135. Kim, K.; Cho, K.H.; Im, S.H.; Choi, J.; Yu, J.; Kim, M. Decrement of Serum Vitamin D Level After Stroke. Ann. Rehabil. Med. 2017, 41, 944-950. [CrossRef] [PubMed]

136. Artaza, J.N.; Mehrotra, R.; Norris, K.C. Vitamin D and the cardiovascular system. Clin. J. Am. Soc. Nephrol. 2009, 4, 1515-1522. [CrossRef] [PubMed]

137. Cannell, J.J.; Grant, W.B.; Holick, M.F. Vitamin D and inflammation. Dermatoendocrinology 2014, 6, e983401. [CrossRef] [PubMed]

138. Cohen-Lahav, M.; Shany, S.; Tobvin, D.; Chaimovitz, C.; Douvdevani, A. Vitamin D decreases NFkappaB activity by increasing IkappaBalpha levels. Nephrol. Dial. Transplant. 2006, 21, 889-897. [CrossRef] [PubMed]

139. Liu, X.; Nelson, A.; Wang, X.; Farid, M.; Gunji, Y.; Ikari, J.; Iwasawa, S.; Basma, H.; Feghali-Bostwick, C.; Rennard, S.I. Vitamin D modulates prostaglandin E2 synthesis and degradation in human lung fibroblasts. Am. J. Respir. Cell Mol. Biol. 2014, 50, 40-50. [PubMed]

140. Penna, G.; Roncari, A.; Amuchastegui, S.; Daniel, K.C.; Berti, E.; Colonna, M.; Adorini, L. Expression of the inhibitory receptor ILT3 on dendritic cells is dispensable for induction of CD4 + Foxp3 + regulatory T cells by 1,25-dihydroxyvitamin D3. Blood 2005, 106, 3490-3497. [CrossRef] [PubMed]

141. Tarcin, O.; Yavuz, D.G.; Ozben, B.; Telli, A.; Ogunc, A.V.; Yuksel, M.; Toprak, A.; Yazici, D.; Sancak, S.; Deyneli, O.; et al. Effect of Vitamin D Deficiency and Replacement on Endothelial Function in Asymptomatic Subjects. J. Clin. Endocrinol. Metab. 2009, 94, 4023-4030. [CrossRef] [PubMed]

142. Marniemi, J.; Alanen, E.; Impivaara, O.; Seppänen, R.; Hakala, P.; Rajala, T.; Rönnemaa, T. Dietary and serum vitamins and minerals as predictors of myocardial infarction and stroke in elderly subjects. Nutr. Metab. Cardiovasc. Dis. 2005, 15, 188-197. [CrossRef] [PubMed]

143. Sun, Q.; Pan, A.; Hu, F.B.; Manson, J.E.; Rexrode, K.M. 25-Hydroxyvitamin D Levels and the Risk of Stroke: A Prospective Study and Meta-analysis. Stroke 2012, 43, 1470-1477. [CrossRef] [PubMed]

144. Cirillo, P.; Golino, P.; Calabro, P.; Calì, G.; Ragni, M.; De Rosa, S.; Cimmino, G.; Pacileo, M.; De Palma, R.; Forte, L.; et al. C-reactive protein induces tissue factor expression and promotes smooth muscle and endothelial cell proliferation. Cardiovasc. Res. 2005, 68, 47-55. [CrossRef] [PubMed]

145. Chen, C.; Nan, B.; Lin, P.; Yao, Q. C-reactive protein increases plasminogen activator inhibitor-1 expression in human endothelial cells. Thromb. Res. 2008, 122, 125-133. [CrossRef] [PubMed]

146. Hattori, Y.; Matsumura, K.K.; Kasai, K. Vascular smooth muscle cell activation by C-reactive protein. Cardiovasc. Res. 2003, 58, 186-195. [CrossRef]

147. Pilz, S.; Tomarchitz, A.; Drechsler, C.; Zittermann, A.; Dekker, J.M.; März, W. Vitamin [8]D supplementation: A promising approach for the prevention and treatment of strokes. Curr. Drug Targets 2011, 12, 88-96. [CrossRef] [PubMed]

148. Park, K.Y.; Chung, P.W.; Kim, Y.B.; Moon, H.S.; Suh, B.C.; Won, Y.S.; Kim, J.M.; Youn, Y.C.; Kwon, O.S. Serum vitamin [9]D status as a predictor of prognosis in patients with acute ischemic stroke. Cerebrovasc. Dis. 2015, 40, 73-80. [CrossRef] [PubMed]

149. Ladeby, R.; Wirenfeldt, M.; Garcia-Ovejero, D.; Fenger, C.; Dissing-Olesen, L.; Dalmau, I.; Finsen, B. Microglial cell population dynamics in the injured adult central nervous system. Brain Res. Brain Res. Rev. 2005, 48, 196-206. [CrossRef] [PubMed]

150. Wei, Z.; Kuang, J. Research Article: Vitamin D deficiency in relation to the poor functional outcomes in nondiabetic patients with ischemic stroke. Biosci. Rep. 2018, 38, BSR20171509. [CrossRef] [PubMed]

151. Bjelakovic, G.; Gluud, L.L.; Nikolova, D.; Whitfield, K.; Wetterslev, J.; Simonetti, R.G.; Bjelakovic, M.; Gluud, C. Vitamin D supplementation for prevention of mortality in adults. Cochrane Database Syst. Rev. 2011, 7, CD007470.

152. Gupta, A.; Prabhakar, S.; Modi, M.; Bhadada, S.K.; Kalaivani, M.; Lal, V.; Khurana, D. Effect of Vitamin D and calcium supplementation on ischaemic stroke outcome: A randomised controlled open-label trial. Int. J. Clin. Pract. 2016, 70, 764-770. [CrossRef] [PubMed]

153. Manson, J.E. Vitamin D and the heart: Why we need large-scale clinical trials. Cleve Clin. J. Med. 2010, 77, 903-910. [CrossRef] [PubMed]

154. LeBoff, M.S.; Yue, A.Y.; Copeland, T.; Cook, N.R.; Buring, J.E.; Manson, J.E. VITAL-Bone Health: Rationale and design of two ancillary studies evaluating the effects of vitamin D and/or omega-3 fatty acid supplements on incident fractures and bone health outcomes in the VITamin D and OmegA-3 TriaL (VITAL). Contemp. Clin. Trials 2015, 41, 259-268. [CrossRef] [PubMed] 
155. Shaffer, J.A.; Edmondson, D.; Wasson, L.T.; Falzon, L.; Homma, K.; Ezeokoli, N.; Li, P.; Davidson, K.W. Vitamin D supplementation for depressive symptoms: A systematic review and meta-analysis of randomized controlled trials. Psychosom. Med. 2014, 76, 190-196. [CrossRef] [PubMed]

156. Karran, E.; Mercken, M.; Strooper, B.D. The amyloid cascade hypothesis for Alzheimer's disease: An appraisal for the development of therapeutics. Nat. Rev. Drug Discov. 2011, 10, 698-712. [CrossRef] [PubMed]

157. Roher, A.E.; Lowenson, J.D.; Clarke, S.; Woods, A.S.; Cotter, R.J.; Gowing, E.; Ball, M.J. Beta amyloid (1-42) is a major component of cerebrovascular amyloid deposits: Implications for the pathology of Alzheimer's disease. Proc. Natl. Acad. Sci. USA 1993, 90, 10836-10840. [CrossRef] [PubMed]

158. Choi, S.H.; Kim, Y.H.; Hebisch, M.; Sliwinski, C.; Lee, S.; D'Avanzo, C.; Chen, H.; Hooli, B.; Asselin, C.; Muffat, J.; et al. A three dimensional human neural cell culture model of Alzheimer's disease. Nature 2014, 515, 274-278. [CrossRef] [PubMed]

159. Lahiri, D.K.; Maloney, B. The LEARn (Latent early life associated regulation) model integrates environmental risk factors and the developmental basis of Alzheimer's disease, and proposes remedial steps. Exp. Gerontol. 2010, 45, 291-296. [CrossRef] [PubMed]

160. Banerjee, A.; Khemka, V.K.; Gaungly, A.; Roy, D.; Gauguly, U.; Chakrabarti, S. Vitamin D and Alzheimer's Disease: Neurocognition to therapeutics. Int. J. Alzheimers Dis. 2015, 2015. [CrossRef] [PubMed]

161. Gezen, A.K.D.; Dursun, B.; Bilgic, B.; Hanağasi, H.; Ertan, T.; Gürvit, H.; Emre, M.; Eker, E.; Ulutin, T.; Uysal, O; et al. Vitamin D receptor gene haplotype is associated with late-onset Alzheimer's Disease. Tohoku J. Exp. Med. 2012, 228, 189-196. [CrossRef]

162. Dursun, E.; Gezen Ak, D.; Ylmazer, S. A new mechanism for amyloid Beta induction of iNOS: Vitamin D-VDR pathwy disruption. J. Alzheimers Dis. 2013, 36, 459-474. [CrossRef] [PubMed]

163. Brewer, L.D.; Thibault, V.; Chen, K.C.; Langub, M.C.; Landfield, P.W.; Porter, N.M. Vitamin D hormone confers neuroprotection in parallel with downregulation of L-type calcium channel expression in hippocampal neurons. J. Neurosci. 2001, 21, 98-108. [CrossRef] [PubMed]

164. Thibault, O.; Landfield, P.W. Increase in single L-type calcium channels in hippocampal neurons during aging. Science 1996, 272, 1017-1020. [CrossRef] [PubMed]

165. Porter, N.M.; Thibault, O.; Thibault, V.; Chen, K.C.; Landfield, P.W. Calcium-channel density and hippocampal cell death with age in long-term culture. J. Neurosci. 1997, 17, 5629-5639. [CrossRef] [PubMed]

166. Gezen-Ak, D.; Dursun, E.; Yilmazer, S. Vitamin D inquiry in hippocampal neurons: Consequences of vitamin D-VDR pathway disruption on calcium channel and the vitamin D requirement. Neurol. Sci. 2013, 34, 1453-1458. [CrossRef] [PubMed]

167. Wang, L.; Har, K.; Van Baaren, J.M.; Price, J.C.; Beecham, G.W.; Gallins, P.J.; Whitehead, P.L.; Wang, G.; Lu, C.; Slifer, M.A.; et al. Vitamin D receptor and AD: A genetic and functional study. Neurobiol. Aging 2012, 33, 1844.e1-1844.e9. [CrossRef] [PubMed]

168. Kuningans, M.; Mooijart, S.P.; Jolles, J.; Slagboom, P.E.; Westendorp, R.G.; van Heemst, D. VDR genes variants associate with cognitive functions and depressive symptom in old age. Neurobiol. Aging 2009, 30, 466-473. [CrossRef] [PubMed]

169. Buell, J.S.; Dawson-Hughes, B.; Scott, T.M.; Weiner, D.E.; Dallal, G.E.; Qui, W.Q.; Bergethon, P.; Rosenberg, I.H.; Folstein, M.F.; Patz, S.; et al. 25-Hydroxyvitamin D, dementia and cerebrovascular pathology in elders receiving home services. Neurology 2010, 74, 18-26. [CrossRef] [PubMed]

170. Grimm, M.O.W.; Lehmann, J.; Mett, J.; Zimmer, V.C.; Grösgen, S.; Stahlmann, C.P.; Hundsdörfer, B.; Haupenthal, V.J.; Rothhaar, T.L.; Herr, C.; et al. Impact of vitamin D on amyloid precursor protein processing and amyloid beta peptide degradation in Alzheimer's Disease. Neurodegen. Dis. 2014, 13, 75-81. [CrossRef] [PubMed]

171. Miziwicki, M.T.; Menegaz, D.; Zhang, J.; Barrientos-Durán, A.; Tse, S.; Cashman, J.R.; Griffin, P.R.; Fiala, M. Genomic and nongenomic signaling induced by 1 alpha $25 \mathrm{OH} 2$ vitamin D3 promotes the recovery of amyloid phagocytosis by Alzheimer's disease macrophages. J. Alzheimers Dis. 2012, 29, 51-62. [CrossRef] [PubMed]

172. Taniura, H.; Ito, M.; Sanada, N.; Kuramoto, N.; Ohno, Y.; Nakamichi, N.; Yoneda, Y. Chronic vitamin d3 treatment protects against neurotoxicity by glutamate in association with upregulation of vitamin $\mathrm{D}$ receptor mRNA expression in cultured rat cortical neurons. J. Neurosci. Res. 2006, 83, 1179-1189. [CrossRef] [PubMed] 
173. Garcion, E.; Sindij, L.; Leblondel, G.; Brachet, P.; Darcy, F. 1-25 dihydroxyvitamin D3 regulates the synthesis of gamma glutamyl transpeptidase and gluthatione levels in rat primary astrocytes. J. Neurochem. 1999, 73, 859-866. [CrossRef] [PubMed]

174. Briones, T.L.; Darwish, H. Decrease in age related tau hyperphosphorylation and cognitive improvement following vitamin D supplementation are associated with modulation of brain energy metabolism and redox state. Neuroscience 2014, 262, 143-155. [CrossRef] [PubMed]

175. Thomas, M.K.; Lloyd-Jones, D.M.; Thadani, R.I.; Shaw, A.C.; Deraska, D.J.; Kitch, B.T.; Vamvakas, E.C.; Dick, I.M.; Prince, R.L.; Finkelstein, J.S. Hypovitaminosis D in medical inpatients. N. Engl. J. Med. 1998, 338, 777-783. [CrossRef] [PubMed]

176. Gloth, F.M.; Gundberg, C.M.; Hollis, B.W.; Haddad, J.G.; Tobin, J.D. Vitamin D deficiency in homebound elderly persons. JAMA 1995, 274, 1683-1686. [CrossRef] [PubMed]

177. Moon, J.H.; Lim, S.; Han, J.W.; Kim, K.M.; Choi, S.H.; Kim, K.W.; Jang, H.C. Serum 25-hydroxyvitamin D level and the risk of mild cognitive impairment and dementia: The Korean Longitudinal Study on Health and Aging (KloSHA). Clin. Endocrinol. 2015, 83, 36-42. [CrossRef] [PubMed]

178. Khachaturian, Z.S. The role of calcium regulation in brain aging: Reexamination of a hypothesis. Aging 1989, 1, 17-34. [CrossRef] [PubMed]

179. Annweiler, C.; Montero-Odasso, M.; Llewellyn, D.J.; Richard Devantoy, S.; Duque, G.; Beauchet, O. Meta-analysis of memory and executive dysfunctions in relation to vitamin D. J. Alzheimers Dis. 2013, 37, 147-171. [CrossRef] [PubMed]

180. Annweiler, C.; Rolland, Y.; Schott, A.M.; Blain, H.; Vellas, B.; Herrmann, F.R.; Beauchet, O. Higher vitamin D dietary intake is associated with lower risk of AD: A 7-year follow-up. J. Gerontol. Ser. A Biol. Sci. Med. Sci. 2012, 67, 1205-1211. [CrossRef] [PubMed]

181. Fiala, M.; Miziwiki, M.T. Neuroprotective and immune effects of active forms of vitamin D3 and docosahexaenoic acid in AD patients. Funct. Foods Health Dis. 2011, 1, 545-554.

182. Annweiler, C.; Herrmann, F.R.; Fantino, B.; Brugg, B.; Beauchet, O. Effectiveness of the combination of memantine plus vitamin D on cognition in patients with AD: A pre-post pilot study. Cognit. Behav. Neurol. 2012, 25, 121-127. [CrossRef] [PubMed]

183. Stein, M.S.; Schere, S.C.; Ladd, K.S.; Harrison, L.C. A randomized controlled trial of high dose vitamin D2 followed by intranasal insulin in, A.D. J. Alzheimers Dis. 2011, 26, 477-484. [CrossRef] [PubMed]

184. Przybelski, R.; Agrawal, S.; Krueger, D.; Engelke, J.A.; Walbrun, F.; Binkley, N. Rapid correction of low vitamin D status in nursing home residents. Osteoporos. Int. 2008, 19, 1621-1628. [CrossRef] [PubMed]

185. LaPrincess, C.B.; Michos, E.D.; Reis, J.P. Vitamin D in atherosclerosis, vascular disease, and endothelial function. Curr. Drug Targets 2011, 12, 54-60.

186. Prabhakar, P.; Chandra, S.R.; Supriya, M.; Issac, T.G.; Prasad, C.; Christopher, R. Vitamin D status and vascular dementia due to cerebral small vessel disease in the elderly Asian Indian population. J. Neurol. Sci. 2015, 359, 108-111. [CrossRef] [PubMed]

187. Alagiakrishnan, K.; Hsueh, J.; Zhang, E.; Khan, K.; Senthilselvan, A. Small vessel disease/white matter disease of the brain and its association with osteoporosis. J. Clin. Med. Res. 2015, 7, 297-302. [CrossRef] [PubMed]

188. Chung, P.W.; Park, K.Y.; Lim, J.M.; Shin, D.W.; Park, M.S.; Chung, Y.J.; Ha, S.Y.; Ahn, S.W.; Shin, H.W.; Kim, Y.B.; et al. 25-Hydroxyvitmain D status is associated with chronic cerebral small vessel disease. Stroke 2015, 46, 248-251. [CrossRef] [PubMed]

189. Mancuso, P.; Rahman, A.; Hershey, S.D.; Dandu, L.; Nibbelink, K.A.; Simpson, R.U. 1,25-Dihydroxyvitamin-D3 treatment reduces cardiac hypertrophy and left ventricular diameter in spontaneously hypertensive heart failure-prone $(\mathrm{cp} /+)$ rats independent of changes in serum leptin. J. Cardiovasc. Pharmacol. 2008, 51, 559-564. [CrossRef] [PubMed]

190. Bodyak, N.; Ayus, J.C.; Achinger, S.; Shivalingappa, V.; Ke, Q.; Chen, Y.S.; Debra, L.R.; Isaac, S.; Hector, T.; Paul, E.K.; et al. Activated vitamin D attenuates left ventricular abnormalities induced by dietary sodium in DAHL salt-sensitive animals. Proc. Natl. Acad. Sci. USA 2007, 104, 16810-16815. [CrossRef] [PubMed]

191. Wang, T.J.; Pencina, M.J.; Booth, S.L.; Jacques, P.F.; Ingelsson, E.; Lanier, K.; Benjamin, E.J.; D’Agostino, R.B.; Wolf, M.; Vasan, R.S. Vitamin D deficiency and risk of cardiovascular disease. Circulation 2008, 117, 503-511. [CrossRef] [PubMed] 
192. Zittermann, A.; Schleithoff, S.S.; Tenderich, G.; Berthold, H.K.; Körfer, R.; Stehle, P. Low vitamin D status a contributing factor in the pathogensis of congestive heart failure? J. Am. Coll. Cardiol. 2003, 41, 105-112. [CrossRef]

193. Somjen, D.; Weisman, Y.; Kohen, F.; Gayer, B.; Limor, R.; Sharon, O.; Jaccard, N.; Knoll, E.; Stern, N. 25-hydroxyvitamin D3-1alpha-hydroxylase is expressed in human vascular smooth muscle cells and is upregulated by parathyroid hormone and estrogenic compounds. Circulation 2005, 111, 1666-1671. [CrossRef] [PubMed]

194. Danielsson, C.; Nayeri, S.; Wiesinger, H.; Thieroff-Ekerdt, R.; Carlberg, C. Potent gene regulatory and antiproliferative activities of 20-methyl analogues of 1,25 dihydroxyvitamin D3. J. Cell. Biochem. 1996, 63, 199-206. [CrossRef]

195. Eyles, D.W.; Burne, T.H.J.; McGrath, J.J. Vitamin D effects on brain development, adult brain function and the links between low levels of vitamin D and neuropsychiatric disease. Front. Neuroendocrinol. 2013, 34, 47-64. [CrossRef] [PubMed]

196. Almeras, L.; Eyles, D.; Benech, P.; Laffite, D.; Villard, C.; Patatian, A.; Boucraut, J.; Mackay-Sim, A.; McGrath, J.; Féron, F. Developmental vitamin D deficiency alters brain protein expression in the adult rat: Implications for neuropsychiatric disorders. Proteomics 2007, 7, 769-780. [CrossRef] [PubMed]

197. Sutherland, M.K.; Somerville, M.J.; Yoong, L.K.K.; Bergeron, C.; Haussler, M.R.; Crapper McLachlan, D.R. Reduction of vitamin D hormone receptor mRNA levels in Alzheimer as compared to Huntington hippocampus: Correlation with calbindin-28k mRNA levels. Mol. Brain Res. 1992, 3, 239-250. [CrossRef]

198. Moretti, R.; Furlanis, G.; Caruso, P.; Signori, R.; Gazzin, S.; Tiribelli, C. Vitamin D in the Small Vessel disease. Curr. Neurobiol. 2017, 8, 112-124.

199. Li, Y.C.; Kong, J.; Wei, M.; Chen, Z.F.; Liu, S.Q.; Cao, L.P. 1,25 Dihydroxyvitamin D(3) is a negative endocrine regulator of the renin-angiotensin system. J. Clin. Investig. 2002, 110, 229-238. [CrossRef] [PubMed]

200. Buell, J.S.; Dawson-Hughes, B. Vitamin D and neurocognitive dysfunction: Preventing “D”ecline. Mol. Asp. Med. 2008, 29, 415-422. [CrossRef] [PubMed]

201. De Silva, T.M.; Miller, A.A. Cerebral small vessel disease: Targeting oxydative stress as a novel therapeutic strategy. Front. Pharmacol. 2016. [CrossRef] [PubMed]

202. Miller, A.A.; Drummond, G.R.; De Silva, T.M.; Mast, A.E.; Hickey, H.; Williams, J.P.; Broughton, B.R.; Sobey, C.G. NADPH oxidase activity is higher in cerebral versus systemic arteries of four animal species: Role of Nox2. Am. J. Physiol. Heart Circ. Physiol. 2009, 296, 220-225. [CrossRef] [PubMed]

203. Kong, X.F.; Zhi, X.H.; Pei, Y.L.; Jackson, D.M.; Holick, M.F. Molecular cloning, characterization, and promoter analysis of the human 25-hydroxyvitamin D3-1aplha.hydroxyalse gene. Proc. Natl. Acad. Sci. USA 1999, 96, 6988-6993. [CrossRef] [PubMed]

204. Timms, P.M.; Mannan, N.; Hitman, G.A.; Noonan, K.; Mills, P.G.; Syndercombe-Court, D.; Aganna, E.; Price, C.P.; Boucher, B.J. Circualtion MMMP9, vitamin D, and variation in the TIMP-1 response with VDR genotype: Mechanism for inflammatory damage in chronic disorders. QJM 2002, 95, 787-796. [CrossRef] [PubMed]

205. Raymond, M.A.; Desrmeaux, A.; Labelle, A.; Soulez, M.; Soluez, G.; Langelier, Y.; Pshezhetsky, A.V.; Hébert, M.J. Endothelial stress induces the release of vitamin D binding protein, a novel growth factor. Biochem. Biophys. Res. Commun. 2005, 338, 1374-1382. [CrossRef] [PubMed]

206. Nakagawa, K.; Sasaki, Y.; Kato, S.; Kubodera, N.; Okano, T. 22-oxa-1-alpha,25 dyhydroxyvitamin D3 inhibits metastastasis and angiogenesis in lung cancer. Carcinogensesis 2005, 26, 1044-1054. [CrossRef] [PubMed]

207. Zittermnann, A.; Koerfer, R. Protective and toxic effects of vitamin D on vascular calcification: Clinical implications. Mol. Asp. Med. 2008, 29, 423-432. [CrossRef] [PubMed]

208. Andress, D.I. Non classical aspects of differential vitamin D receptor activation. Drugs 2007, 67, 1999-2012. [CrossRef] [PubMed]

209. Williamson, J.B.; Lewis, G.F.; Nyenhuis, D.L.; Stebbins, G.T.; Murphy, C.; Handelman, M.; Harden, E.; Harden, E.; Heilman, K.M.; Gorelick, P.B.; Porges, S.W. The effects of cerebral white matter changes on cardiovascular responses to cognitive and physical activity in a stroke population. Psychophysiology 2012, 49, 1618-1628. [CrossRef] [PubMed]

210. Laurent, S.; Katsahian, S.; Fassot, C.; Tropeano, A.I.; Gautier, I.; Laloux, B.; Boutouyrie, P. Aortic stiffness is an independent predictor of fatal stroke in essential hypertension. Stroke 2003, 34, 1203-1206. [CrossRef] [PubMed] 
211. Baumbach, G.L.; Heistad, D.D. Adaptive changes in cerebral blood vessels during chronic hypertension. J. Hypertens. 1991, 9, 987-991. [CrossRef] [PubMed]

212. Huneau, C.; Benali, H.; Chabriat, H. Investigating human neurovascular coupling using functional neuroimaging: A critical review of dynamic models. Front. Neurosci. 2015, 9, 467. [CrossRef] [PubMed]

213. Phillips, A.A.; Chan, F.H.N.; Zheng, M.M.Z.; Krassioukov, A.V.; Ainslie, P.N. Neurovascular coupling in human: Physiology, methodological advances and clinical implications. JCBFM 2016, 36, 647-664. [CrossRef] [PubMed]

214. Kitazono, T.; Faraci, F.M.; Tagchi, H.; Heistad, D.D. Role of potassium channels in cerebral blood vessels. Stroke 1995, 26, 1713-1723. [CrossRef] [PubMed]

215. Nelson, M.T.; Patlak, J.B.; Worley, J.F.; Standen, N.B. Calcium channels, potassium channels, and voltage dependence of arterial smooth muscle tone. Am. J. Physiol. 1990, 259, 3-18. [CrossRef] [PubMed]

216. Bolotina, V.; Gericke, M.; Bregoestovski, P. Kinetic differences between calcium activate potassium channels in smooth muscle isolated from normal and atherosclerotic human aorta. Proc. R. Soc. Lond. B Biol. Sci. 1991, 244, 51-55. [CrossRef] [PubMed]

217. Cui, X.; Pelekanos, M.; Liu, P.Y.; Burne, T.H.J.; McGrath, J.J.; Eyles, D.W. The vitamin D receptor in dopamine neurons; its presence in human substantia nigra and its ontogenesis in rat midbrain. Neuroscience 2013, 236, 77-87. [CrossRef] [PubMed]

218. Abou Raya, S.; Helmii, M.; Abou Raya, A. Bone and mineral metabolism in older adults with Parkinson's disease. Age Ageing 2009, 38, 675-680. [CrossRef] [PubMed]

219. Lu'o'ng, K.; Nguyen, L. Role of vitamin D in Parkinson's Disease. Int. Sch. Res. Netw. 2012, 2012, 124289.

220. Fiszer, U.; Mix, E.; Fredrikson, S.; Kostulas, V.; Link, H. Parkinson's disease and immunological abnormalities increase of HLA-DR expression on monocytes in cerebrospinal fluid and of CD45ro+ T cells in peripheral blood. Acta Neurol. Scand. 1994, 90, 160-166. [CrossRef] [PubMed]

221. McGeer, P.L.; Itagaki, S.; Boyes, B.E.; McGeer, E.G. Reactive microglia are positive for HLA-DR in the substantia nigra of PD and AD' disease brain. Neurology 1988, 38, 1285-12919. [CrossRef] [PubMed]

222. Tokuda, N.; Levy, R.B. 1,25 Dihydroxyvitamin D3 stimulates phagocytosis but suppresses HLA-DR and CD13 antigen expression in human mononuclear phagocytes. Proc. Soc. Exp. Biol. Med. 1996, 211, $244-250$. [CrossRef] [PubMed]

223. Tone, T.; Eto, K.; Katsuoka, K.; Nishioka, K.; Nishiyama, S. Suppression of gamma interferon induced HLA-DR antigen expression on normal and transformed keratocytes by $1,25(\mathrm{OH})_{2}$ vitamin D3. Jpn. J. Dermatol. 1991, 101, 519-525.

224. Stefanovic, M.; Topic, E.; Khanna, V.K.; Shukla, R.; PArmar, D. Association of polymorphism in cytochrome P450 2D6 and N-Acetyltransferase-2 with Parkinson's disease. Dis. Mark. 2010, 28, 87-93.

225. Singh, S.; Singh, K.; Patel, D.K.; Singh, C.; Nath, C.; Singh, V.K.; Singh, R.K.; Singh, M.P. The expression of cyp2d33, an ortholog of human cyp2D6 in mouse striatum and its modulation in 1-MPTP induced PD phenotype and nicotine-mediated neuroprotection. Rejuv. Res. 2009, 12, 185-197. [CrossRef] [PubMed]

226. Shojaee, S.; Sina, F.; Bnihossein, S.; Kazemi, M.H.; Kalhor, R.; Shahidi, G.A.; Fakhrai-Rad, H.; Ronaghi, M.; Elahi, E. Genome-wide linkage analysis of a parkinsonian pyramidal syndrome pedigree by $500 \mathrm{~K}$ SNP arrays. Am. J. Hum. Genet. 2008, 82, 1375-1384. [CrossRef] [PubMed]

227. Wilhelmsen, K.; Mirel, D.; Marder, K.; Bernstein, M.; Naini, A.; Leal, S.M.; Cote, L.J.; Tang, M.X.; Freyer, G.; Graziano, J.; et al. Is there a genetic susceptibility locus for PD on chromosome 22q13? Ann. Neurol. 1997, 41, 813-817. [CrossRef] [PubMed]

228. Stagi, S.; Lapi, E.; Gambiner, E.; Manoni, C.; Genuardi, M.; Colarusso, G.; Conti, C.; Chiarelli, F.; de Martino, M.; Azzari, C. Bone density and metabolism in subjects with microdeletion of chromosome 22q11. Eur. J. Endocr. 2010, 163, 329-337. [CrossRef] [PubMed]

229. Ryu, H.; Lee, J.; Zamam, K.; Kubilis, J.; Ferrante, R.J.; Ross, B.D.; Neve, R.; Ratan, R.R. Sp1 and Sp3 are oxidative stress-inducible, anti-death transcription factors in cortical neurons. J. Neurosci. 2003, 23, 3597-3606. [CrossRef] [PubMed]

230. Wang, J.; BAnnon, M.J. Sp1 and Sp3 activate transcription of the human dopamine transporter gene. J. Neurochem. 2005, 93, 474-482. [CrossRef] [PubMed]

231. Yajima, S.; Lee, S.H.; Minowa, T.; Mouradian, M.M. Sp family transcription factors regulate expression of rat D2 dopamine receptor gene. DNA Cell Biol. 1998, 17, 471-479. [CrossRef] [PubMed] 
232. Choi, J.M.; Hong, J.H.; Chae, M.J.; Ngyuen, P.H.; Kang, H.S.; Ma, H.I.; Kim, Y.J. Analysis of mutations and the association between polymorphisms in the cerebral dopamine neurotrophic factor (CDNF) gene and, P.D. Neurosci. Lett. 2011, 493, 97-101. [CrossRef] [PubMed]

233. Baranano, D.; Snyder, S.H. Neural roles for heme oxygenase: Contrasts to nitric oxide synthase. Proc. Natl. Acad. Sci. USA 2001, 98, 10996-11002. [CrossRef] [PubMed]

234. Mateo, I.; Infante, J.; Sanchez-Juan, P.; García-Gorostiaga, I.; Rodríguez-Rodríguez, E.; Vázquez-Higuera, J.L.; Berciano, J.; Combarros, O. Serum heme oxygenase-1 levels are increased in PD but not in, A.D. Acta Neurol. Scand. 2010, 121, 136-138. [CrossRef] [PubMed]

235. Castellani, R.; Smith, M.A.; Richey, P.L.; Perry, G. Glycoxidation and oxidative stress in PD and diffuse Lewy body disease. Brain Res. 1996, 737, 195-200. [CrossRef]

236. Oermann, E.; Bidmon, H.J.; Witte, O.W.; Zilles, K. Effects of 1 alpha, 25 dihydroxyvitamin D3 on the expression of HO1 and GFAP in glial cells of the photothrombotically lesioned cerebral cortex. J. Chem. Neuroanat. 2004, 28, 225-238. [CrossRef] [PubMed]

237. Soos, J.; Engelhardt, I.; Siklos, L.; Havas, L.; Majtenyi, K. The expression of PARP, NF- kB and parvalbumin is increased in, O.D. Neuroreport 2004, 15, 1715-1718. [CrossRef] [PubMed]

238. Mabley, J.G.; Wallace, R.; Pacher, P.; Murphy, K.; Szabo, C. Inhibition of PARP polymerase by the active form of vitamin D. Int. J. Mol. Med. 2007, 19, 947-952. [PubMed]

239. Suzuki, M.; Yoshioka, M.; Hashimoto, M.; Murakami, M.; Noya, M.; Takahashi, D.; Urashima, M. Randomized, double-blind, placebo-controlled trial of vitamin D supplement in Parkinson's disease. Am. J. Clin. Nutr. 2013, 97, 1004-1013. [CrossRef] [PubMed]

240. Ohmura, K.; Kato, M.; Watanabe, T.; Oku, K.; Bohgaki, T.; Horita, T.; Yasuda, S.; Ito, Y.M.; Sato, N.; Atsumi, T. Effect of combined treatment with bisphosphonate and vitamin $\mathrm{D}$ on atherosclerosis in patients with systemic lupus erythematosus: A propensity scorebased analysis. Arthrit. Res. Ther. 2018, 20, 72. [CrossRef] [PubMed]

241. Aydoğan, N.H.; Özel, İ.; İltar, S.; Kara, T.; Özmeriç, A.; Alemdaroğlu, K.B. The effect of vitamin D and bisphosphonate on fracture healing: An experimental study. J. Clin. Orthop. Trauma 2016, 7, 90-94. [CrossRef] [PubMed]

242. Kang, Y.M.; Hong, S.H.; Yang, J.H.; Oh, J.C.; Park, J.O.; Lee, B.H.; Lee, S.Y.; Kim, H.S.; Lee, H.M.; Moon, S.H. Pamidronate down-regulates tumor necrosis factor-alpha induced matrix metalloproteinases expression in human intervertebral disc cells. J. Bone Metab. 2016, 23, 165-173. [CrossRef] [PubMed]

243. Kennel, K.A.; Drake, M.T.; Hurley, D.L. Vitamin D Deficiency in Adults: When to Test and How to Treat. Mayo Clin. Proc. 2010, 85, 752-758. [CrossRef] [PubMed] 